\title{
Spatio-temporal variations in intertidal mudflat erodability: Marennes- Oléron Bay, western France
}

\author{
F. Orvain ${ }^{a},{ }^{*}$, P.-G. Sauriau ${ }^{b}$, P. Le Hir ${ }^{c}$, G. Guillou ${ }^{b}$, P. Cann ${ }^{c}$ and M. Paillard ${ }^{c}$
}

\begin{abstract}
aLaboratoire PE2M (Physiologie et Ecophysiologie des Mollusques Marins), Université de Caen, Esplanade de la Paix, 14032 Caen cedex, France

${ }^{\mathrm{b}}$ CREMA (CNRS-IFREMER, UMR 10), Centre de Recherche sur les Ecosystèmes Marins et Aquacoles de l'Houmeau, Place du Séminaire, B.P. 5, 17137, L'Houmeau, France

'IFREMER, Centre de Brest, B.P. 70, 29280 Plouzané, France
\end{abstract}

*: Corresponding author : F. Orvain, email address : F.Orvain@iutcaen.unicaen.fr

\begin{abstract}
:
A portable erosion device (ERIS) was deployed in November 2000 and May 2001 to investigate the spatio-temporal variation of fine-grained sediment erosion over a transect on the intertidal mudflats of Marennes-Oléron Bay, western France. The objective was to relate changes in bed erodability over diurnal emersion periods to bioturbation, rapid changes in sediment characteristics, and microphytobenthos biomass.

Macrofaunal assemblages were dominated by the bivalve, Scrobicularia plana, on the upper mudflat, and by the gastropod, Hydrobia ulvae, on the middle mudflat. A power relationship was obtained where Tcr was plotted as a function of sediment density. Results from the upper part of the mudflat deviated from this relationship due to bioturbation by S. plana. No influence of microphytobenthos (either chlorophyll a or extracellular polymeric substances (EPS) content) was found on Tcr. The bivalve feeding activities altered consolidated sediments (sediment dry mass concentration of not, vert, similar700 $\mathrm{g} \mathrm{I}-1)$ so that they became resuspended easily $(\mathrm{Tcr}<1 \mathrm{~Pa})$. Fluff layer erosion was observed, with an erosion rate dependent upon the biomass of $\mathrm{H}$. ulvae. It was also found that bioturbation by $\mathrm{H}$. ulvae was implicated (combined with grazing activities) in chl a resuspension during the erosion of the fluff layer. Snail bioturbation stimulated the chl a enrichment of eroded material, whilst the high snail biomass produced a decrease in suspended chl a due to higher grazing rates.
\end{abstract}

Keywords: Eris; Resuspension; Bioturbation; Hydrobia ulvae; Scrobicularia plana; Sediment; Intertidal mudflat; Erodability; Microphytobenthos; EPS 


\section{Introduction}

Marine macrofaunal activities alter fine-grained sediment erodability (Rhoads and Young, 1970; Nowell et al., 1981; Grant and Daborn, 1994; Willows et al., 1998; Widdows et al., 2000; Andersen, 2001) through the production of a surface layer, which is eroded easily when compared with the bulk sediment matrix. Each deposit-feeder species contributes to the creation of this surface layer, called the "biogenic fluff layer", which comprises low-density, mucusenriched aggregates, which are eroded before general bed failure. For instance, bivalves (especially tellinids like Macoma balthica and Scrobicularia plana) produce large amounts of pseudofecal material that constitute a high proportion of the eroded mass at every tidal cycle (Willows et al., 1998; Wood and Widdows, 2002; Orvain, 2005). In contrast, the effects of the gastropod Hydrobia ulvae are related mainly to its surface tracks at the sediment-water interface (Orvain and Sauriau, 2002; Orvain et al., 2003b and Orvain et al., 2004). Consequently, this snail species has a more limited action in terms of the quantity of mass eroded compared to the bivalves cited (Andersen et al., 2002; Orvain et al., 2006). The dominance of different groups can vary depending upon the location and season, hence the macrobenthic assemblage of an ecosystem must be included in an evaluation of spatio-temporal differences in bed erodability.

The extent to which bioturbation alters bed erodability depends upon environmental factors (Widdows et al., 2000) which, over intertidal mudflats, are subject to tidally-induced changes in addition to seasonal ones. Sediment density and microphytobenthic biofilm status, which are both mediated by tidal and light cycles, also affect macrofaunal animal activities and thus the intensity of bioturbation (Orvain and Sauriau, 2002).

The importance of deposit-feeder activities (bioturbation and grazing) on the condition of the sediment-water interface suggests a role for macrofauna in microalgae resuspension. Microalgal cells accumulate at the sediment-water interface due to: (1) upward movements of microphytobenthos during emersion periods; and (2) sinking of phytoplankton during deposition. This implies a discontinuity between sediment and chlorophyll a resuspension, and a sequential resuspension among heterotrophic protistan groups (Wiltshire et al., 1998; Lucas et al., 2000; Shimeta et al., 2002). The importance of deposit-feeder activities on the behaviour of the sediment-water interface suggests that macrofauna play an essential role in the regulation of microalgal resuspension (Orvain et al., 2004). In this sense, microphytobenthic resuspension must reflect the combined effects of macrofauna bioturbation and grazing. This has been established clearly for $\mathrm{H}$. ulvae during laboratory flume experiments (Blanchard et al., 1997; Orvain et al., 2004), however little is known about such effects, especially in natural settings.

The present study aims to assess the extent that biological and physical factors affect bed erodability, at a site on the Montportail-Brouage mudflat, French Atlantic coast. The objectives are to examine: (1) short-term changes in sediment erodability in response to bioturbation, and diurnal changes of sediment properties due to microphytobenthic development and/or dewatering-drainage processes; (2) whether laboratory findings on the role of bioturbation in the creation of a surface layer are relevant in the field; (3) the role of variations in bed erodability for microalgal resuspension; and (4) whether there is a seasonal component in these processes.

\section{Materials and methods}

\subsection{Study site}

Intertidal mudflats in the macrotidal Marennes-Oléron Bay occur along two sides of a north-south orientated, sinuous channel that begins south of the lle d'Oléron and widens to the north, creating a bay between the island and the mainland (Fig. 1). The waters are often very turbid due to the Charente River input, and the resuspension of sediment from intertidal mudflats in the bay. The bay has a total area of about $170 \mathrm{~km} 2$, of which $60 \%$ is mudflats. The spring tidal range is about $6 \mathrm{~m}$. On the mainland (i.e. eastern) side of the bay, the intertidal area is $20 \mathrm{~km}$ long and $4.5 \mathrm{~km}$ 
wide, and is located between the Seudre River and the Charente River (see Fig. 1). This area is referred to as the Brouage mudflats, with $92 \%$ of the sediments in this region composed mainly of clay minerals, with a mean particle size $<63 \mu \mathrm{m}$ (Galois et al., 2000). The mudflats display a variety of bedforms (Gouleau et al., 2000). The mid-tidal areas are covered by a system of shorenormal ridges and runnels (Dyer et al., 2000) (see Fig. 1), whereas the upper flat (500 m wide) is highly variable in structure due to meteorological events (Gouleau et al., 2000). During periods of east winds, high sedimentation of fluid mud can occur, rendering it flat (Gouleau et al., 2000). Under the influence of west winds, the fluid muds are resuspended, revealing criss-crossed pseudo-ripples.

Three reference sites were established along the mudflat portion of a cross-shore transect (Fig. 1) that had been studied previously during the INTRMUD (Mast 3) European project (see The Morphologic Development of Intertidal Mudflats, Cont. Shelf Res. 20, 2000).

\subsection{Experiments and instrumentation}

The ERIS system (Fig. 2) was developed by IFREMER to evaluate bed erodability. The sampling unit $(20 \mathrm{~cm}$ high) is pushed into a flat portion of the sediment bed, and a rectangular sample ( $8 \mathrm{~cm}$ wide, $30 \mathrm{~cm}$ long) collected. Once closed by a sliding system, the sampler is brought back onboard, where it is installed in ERIS, and filled gently with filtered seawater (here: $31 \mathrm{~S}, 15^{\circ} \mathrm{C}$ ). Where the sediment is disturbed during sampling or installation, the sample is discarded and the bed re-sampled. The eroding unit (closed circuit connected to a pump) is placed on top of the sampling unit, and a gap of $2 \mathrm{~cm}$ is adjusted over the sediment. The pressure difference, $\Delta P$, is measured between the downstream and upstream positions in the chamber. Bed roughness and bed shear stress estimates are calculated independently for each experimental run, based on $\Delta P$. Calibrations are based, respectively, upon velocity profiles acquired by acoustic Doppler measurements using plates of varying roughness, and sand particles of known critical erosion threshold for bed roughness values between 0 and $2.5 \mathrm{~mm}$ (smooth to rough flow). This range corresponds to the natural roughness created by shell fragments and burrows made by mudflat organisms, e.g. tellinids.

ERIS (version 2) was deployed during 2 cruises (November 2000 and May 2001) at the 3 stations along the shore-normal transect. Erosion experiments were made at the beginning and end of the emersion periods, at each site. In addition, ERIS was used on the ridge and runnel bedforms at sites 2 and 3. During each of 17 erosion experiments undertaken (Table 1), the flow velocity over the sediment surface was increased in steps of $2.5 \mathrm{~cm} \mathrm{~s}^{-1}$, generally from 2.5 to $30 \mathrm{~cm} \mathrm{~s}^{-1}$. For sediments from the tops of ridges, the stepwise increase was continued to $60-95 \mathrm{~cm} \mathrm{~s}^{-1}$. Time steps were $2 \mathrm{~min}$ long and were increased to $5 \mathrm{~min}$ when general bed erosion was detected visually, in order to observe if a reduction in erosion rate appeared at constant bed shear stress.

Concentrations of suspended particulate matter (SPM in $\mathrm{g} \mathrm{I}^{-1}$ ) and pigment (chl $a$ in $\mu \mathrm{g} \mathrm{I}^{-1}$ ) were monitored at $1 \mathrm{~s}$ intervals in the water column using two optical backscatter sensors (OBS) and a fluorometric probe. The OBSs and the fluorometric probe were calibrated at CREMA, L'Houmeau, France, with mud from the sampling sites. Intercalibration of the two OBSs gave consistent, linear results for all experiments. Resuspension data were converted into sediment mass eroded per unit area $\left(M\right.$, in $\left.\mathrm{kg} \mathrm{m}^{-2}\right)$ according to the formula: $M=S P M(V / S)$, where $V$ is the water volume $\left(=15.5 \times 10^{-3} \mathrm{~m}^{3}\right)$ and $\mathrm{S}$ is the test section surface $\left(=3.2 \times 10^{-2} \mathrm{~m}^{2}\right)$. The saturating value of SPM concentration in our device was $0.6 \mathrm{~g} \mathrm{I}^{-1}\left(385 \mathrm{~g} \mathrm{~m}^{-2}\right.$ in terms of eroded mass), or $0.55 \mathrm{~mm}$ sediment layer height eroded (assuming homogeneous erosion over the sediment sample surface). Resuspended pigment time-series were converted similarly.

Two erosion phases were identified (Fig. 3): (1) fluff layer erosion; and (2) general bed erosion [see Orvain et al. (2003b) and Orvain (2005) for a more detailed description of the erosion phases]. The incipient point of fluff layer erosion was considered as the point at which a significant increase in SPM between two incremental velocity steps was obtained. The critical threshold for fluff layer erosion was determined using a statistical test which compared the means of incremental steps $(n=120)$ between two SPM data sets (significant at $p<0.05)$. Critical erosion threshold $\left(U_{\mathrm{cr}}\right.$, in $\left.\mathrm{cm} \mathrm{s}^{-1}\right)$ was determined from a plot of SPM versus current velocity using best fit 
regression lines from the semi-logarithmic equation, $S P M=A+B \times \log _{10}(U)$ and calculating the solution of the intercept with the baseline, $\mathrm{SPM}=0$. The critical erosion shear stress $\left(I_{\mathrm{cr}}\right.$, in $\left.\mathrm{Pa}\right)$ was determined using a conversion derived from the flume calibration of bed shear stress.

For consolidated beds, the fluff layer was recognised easily by the erosion kinetics, where a clear divergence occurred between the two subsequent phases (Figs. 3B and 3D). In this case, the critical threshold for fluff erosion was very much lower than the critical threshold for bed erosion. For soft sediments, there was a continuous release of sediment during the erosion experiment and the divergence between both erosion phases was less apparent (Figs. 3A and C). When critical threshold values for both erosion phases were the same, it was considered that no fluff layer erosion had occurred, e.g. November 2000, station 1 at the beginning of the low-tide period (see Table 1).

\subsection{Additional bed samples}

Three $1 \mathrm{~m}^{2}$ areas, contiguous with the investigated sites, were sampled at the same time as the erosion experiments to assess short-term variations in moisture content and dry density, as well as chl a and colloidal carbohydrate contents. In the first area, 6 syringe cores ( $3 \mathrm{~cm}$ diameter) were collected, and sectioned immediately at depth intervals of $0-2,2-4,4-6,6-8,8-10,10-15$, $15-20,20-25 \mathrm{~mm}$; the sediment was kept in a cooler with ice packs prior to storage at $-80^{\circ} \mathrm{C}$ in the laboratory. The sediment dry density (in $\mathrm{kg} \mathrm{m}^{-3}$ ) was calculated from moisture content using the following formula:

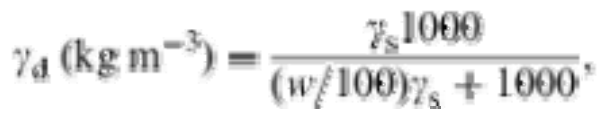

where $\gamma_{\mathrm{s}}$ is the grain density $=2650 \mathrm{~kg} \mathrm{~m}^{-3}$ and $w$ the moisture content ( $\mathrm{g}$ water/g dry sediment $\times 100$ ), obtained after drying at $60^{\circ} \mathrm{C}$ for 3 days. Five cores $(15 \mathrm{~cm}$ diameter) were taken from the second area, to estimate algal biomass and colloidal carbohydrate content. The top $1 \mathrm{~cm}$ was sectioned in the field and kept in a cooler with ice packs prior before storage at $-80^{\circ} \mathrm{C}$. In the third area, 5 random cores $(15 \mathrm{~cm}$ diameter, $30 \mathrm{~cm}$ deep) were taken to evaluate macrofauna populations. Sediment samples were preserved in buffered $4 \%$ formaldehyde, then sieved through a 1-mm mesh in the laboratory.

\subsection{Analyses}

Chloropigments were extracted from $100 \mathrm{mg}$ freeze-dried sediment sample in $90 \%$ methanol, buffered with $10 \%$ ammonium acetate for $1 \mathrm{~h}$ (constant sonification), at $4{ }^{\circ} \mathrm{C}$ in the dark. After centrifugation ( $5 \mathrm{~min}, 2000 \mathrm{~g}$ ), fluorescence of the supernatant was measured using a Turner Fluorometer before and after acidification $\left(10 \mathrm{~mm}^{3} 0.3 \mathrm{M} \mathrm{HCl}\right.$ for $\left.1 \mathrm{~cm}^{3} \mathrm{MeOH}\right)$. Total chl a and phaeopigments were calculated according to the Lorenzen (1966) equations.

Colloidal carbohydrates were extracted from $500 \mathrm{mg}$ freeze-dried sediment in $5 \mathrm{~cm}^{3}$ distilled water for $1 \mathrm{~h}$ at $30^{\circ} \mathrm{C}$, under continuous agitation. After centrifugation $(10 \mathrm{~min}, 2000 \mathrm{~g}), 1 \mathrm{~cm}^{3}$ of the supernatant was used for colloidal carbohydrate analysis. To separate the low molecular weight (LMW) fraction, a further $2 \mathrm{~cm}^{3}$ of supernatant was evaporated at $60{ }^{\circ} \mathrm{C}$ in a dry bath, under a flow of nitrogen gas. The residue was dissolved in $1 \mathrm{~cm}^{3}$ of distilled water and then mixed with $4 \mathrm{~cm}^{3}$ of pure ethanol. This mixture was left overnight at $4{ }^{\circ} \mathrm{C}$ to precipitate, then centrifuged (15 $\mathrm{min}, 4000 \mathrm{~g}$ ) to pelletise the precipitated polymeric fraction. The supernatant ethanol solution was then separated from the pellet, evaporated at $60^{\circ} \mathrm{C}$ under a flow of nitrogen and centrifuged; the resulting pellet was dissolved in $1 \mathrm{~cm}^{3}$ of distilled water to measure the LMW carbohydrate. The ethanol-insoluble material (i.e. the pellet resulting from the initial precipitation) was dissolved in $1 \mathrm{~cm}^{3}$ of distilled water for measurement of EPS (de Brouwer and Stal, 2001; Orvain et al., 2003a). LMW carbohydrate and EPS were quantified by spectrophotometer using the phenolsulphuric acid assay (Dubois et al., 1956) and calibrated standards of d-glucose dissolved in $\mathrm{H}_{2} \mathrm{O}$. 
Macrofauna samples were stained with $0.02 \%$ Rose Bengal and identified to species level (except Oligochaeta). Since Annelids were often broken, only parts with a head structure were counted. The numbers of live individuals were counted under a dissection microscope. The size frequency distributions of dominant species (i.e. S. plana and H. ulvae) were calculated. Shell sizes (from apex to anterior margin of the aperture for $H$. ulvae and shell width for S. plana) were measured using a micrometer (0.1 $\mathrm{mm}$ accuracy). Ash free dry weight (AFDW) biomass was measured after drying specimens at $60^{\circ} \mathrm{C}$ for 3 days, then heating to $550{ }^{\circ} \mathrm{C}$ for $5 \mathrm{~h}$.

ANOVA was used to test spatio-temporal differences for chl a and carbohydrate contents. Homoscedasticity among samples was rejected (Bartlett's test) and a log transformation applied.

\section{Results}

\subsection{Sediment and biological parameters}

In general, trends in the dry density of the surficial sediments were more apparent in November 2000 than in May 2001. At station 1 (upper mudflat), the dry density of the uppermost sediments $(0-2 \mathrm{~mm})$ decreased over the emersion period in November 2000 (Fig. 4A); in contrast, no difference was observed in dry density between the start and end of emersion in May 2001 (Fig. 4B). Geomorphologic structures at station 1 (criss-crossed pseudo-ripples) were not as well defined as the ridge and runnel structures of stations 2 and 3 . The dry density of the uppermost sediment on the ridge tops at stations 2 and 3 (middle and lower-middle mudflat) tended to increase in both November 2000 and May 2001 (Figs. 4C-F). Due to the continuous drainage of sediments from the ridges, sediments deposited in the runnels on the mudflat remained covered by running water throughout low tide. Hence, in contrast to the ridge tops, the dry density of runnel sediments decreased in November 2000 (Fig. 4C) or showed no difference between the start and end of emersion.

There were significant differences between chl $a$ and both the carbohydrate fractions from the various sites and sampling times $(p<0.001$ for each variable). There were also significant differences between November 2000 and May 2001 in terms of chl a content $\left(F_{1,93}=10.07\right.$; $p=0.002)$ and EPS content $(F 1,93=20.4 ; p<0.001)$. In May 2001, the maximum chl a content of $15.5 \mu \mathrm{g} \mathrm{g}-1$ (in the top $1 \mathrm{~cm}$ section) was from the ridge tops at the end of the emersion period, whilst the maximum winter-time chl a content $(12.5 \mu \mathrm{g} \mathrm{g}-1)$ was measured in the runnels of station 2, and was also at the end of the emersion period. Minimum values of 6.1-6.2 $\mu \mathrm{g} g-1$ were found at station 1 in the November 2000 and May 2001 sampling periods (Table 1).

Colloidal carbohydrate contents in May 2001 were higher than those in November 2000. The LMW carbohydrate fraction made up the major part of the colloidal carbohydrates in May 2001, whilst EPS was the dominant fraction in November 2000. The maximum value of the EPS fraction $\left(0.19 \mathrm{mg} \mathrm{g}^{-1}\right)$ was measured in runnels at station 3 during spring. The maximum LMW carbohydrate value $(0.22 \mathrm{mg} \mathrm{g}-1)$ was recorded on top of the ridges at station 2 in May 2001 (Table 1). The LMW carbohydrate fraction was significantly correlated to chl a biomass (Fig. 5A).

The difference between pigment contents measured at the beginning and end of the emersion periods can also be used to estimate net production rates. The values were positive on both the ridge and runnel structures of station 2 in November 2000 and May 2001. At the other stations, the differences were always negative. Net production rates of the colloidal carbohydrate fractions were also estimated. No correlation was found between LMW carbohydrate and chl a production, but there was an inverse relationship between the production rates $\left(\mu \mathrm{g} \mathrm{g}^{-1} \mathrm{~h}^{-1}\right)$ of chl $a$ and EPS (Fig. 5B).

Macrofauna at the sites included Mollusca, Polychaeta, Oligochaeta and Crustacea (Table 2 and Table 3). Although poorly diversified (less than 40 species reported), high biomasses for the macrofauna were recorded along the shore-normal transect (25-35 g AFDW m${ }^{-2}$ ). Overall, the November 2000 macrofaunal biomasses and densities were higher than in May 2001. Annelids and Oligochaeta were especially numerous on the ridge tops at station 3 . The principal phylum recorded was Mollusca, and two species dominated: $\mathrm{H}$. ulvae in terms of animal density, and $S$. plana, in terms of biomass (Table 2 and Table 3; Fig. 6). At station 1, bivalves dominated the 
biomass in November 2000 and May 2001. The S. plana population was best represented on the upper mudflat, where AFDW biomass reached $35.9 \mathrm{~g} \mathrm{~m}^{-2}$ in November 2000 and was $18 \mathrm{~g} \mathrm{~m}^{-2}$ in May 2001. The average individual size of S. plana was higher in November 2000 than in May 2001. For stations 2 and 3, the H. ulvae biomass was more important in November 2000. This species dominated the biomass in runnels at stations 2 and 3 , and the macrofauna densities at all stations in November 2000 (Table 2 and Fig. 6). In May 2001, the biomass for station 2 in the runnels was dominated by S. plana; $\mathrm{H}$. ulvae was dominant on the ridges (Fig. 6). H. ulvae densities ranged between 340-4878 ind. $\mathrm{m}-2$ in November 2000, and 34-1743 ind. m-2 in May 2001. Densities were always higher in runnels than on the tops of ridges. Mean individual size was $3.95 \mathrm{~mm}$ in November 2000 and $4.07 \mathrm{~mm}$ in May 2001. Polychaeta dominated the biomass on the tops of ridges at stations 2 and 3 in November 2000, and on both ridges and runnels at station 3 in May 2001 (Fig. 6): Hediste diversicolor dominated the biomass in both seasons, and Streblospio shrubsolii dominated the density. The density of $S$. shrubsolii reached those of the dominant species, $H$. ulvae, with a maximum of 3418 ind. $\mathrm{m}^{-2}$ in runnels at station 3 in November 2000. The Oligochaete, Tubificoides benedeni, was present at a very high density on top of the ridges at station 2 in May 2001 (Table 3). The density of this species remained low at other sites and times.

\subsection{Bed roughness and critical shear stress}

The pressure difference, $\Delta P$, measured in the ERIS sediment chamber is presented in Fig. 3 . Theoretically, the relationship between the mean velocity $\left(U\right.$, in $\left.\mathrm{cm} \mathrm{s}^{-1}\right)$ and $\Delta P$ is logarithmic, and the $\Delta \mathrm{P}$ kinetics allow the micro-roughness of the bed, ks to be estimated. For each experiment, the averaged values of both parameters, $U$ and $\Delta P$, were calculated at each time step before the critical shear stress for bed erosion. The relationship between both parameters was consistent with the theoretical one (i.e. considering that the roughness was constant), and was used to calculate the bed roughness. However, ks estimates appeared highly variable between experiments and, on 4 occasions, exceeded the limit of $2.5 \mathrm{~mm}$ (Table 1). The variability and the order of magnitude of $k_{\mathrm{s}}$ estimates seemed to represent the natural condition, since $k_{\mathrm{s}}$ was assumed to be zero at the beginning of the emersion periods at stations 2 and 3 , where the sediment beds were flat and therefore hydraulically smooth. Bed roughness increased between the beginning and end of emersion periods, possibly due to snail shells which acted as robust obstacles against the currents. Station 1 had an irregular surface morphology in November 2000. Here, the $k_{\mathrm{s}}$ value was estimated as $1.9 \mathrm{~mm}$ at the beginning of the emersion period, and at $2.1 \mathrm{~mm}$ at the middle of the emersion period. Bed roughness exceeded the measurable range when the tide returned.

\subsection{Variations in bed erodability}

Critical erosion shear stress values varied by a factor of $\sim 10$, and were within the typical range found for consolidated sediments except on the ridge top at station 2, where a value of $2.64 \mathrm{~Pa}$ was found. With the exception of dry density, there was no relationship between $\mathrm{T}_{\mathrm{cr}}$ and the other variables, even when parts of the system were isolated by discriminating between: (1) ridge and runnel data sets; (2) different station data sets; and (3) winter and spring results.

Erosion thresholds plotted as a function of dry sediment density (Fig. 7) indicated that Tcr followed the power law found typically in the laboratory under controlled conditions (Migniot, 1968; Mehta et al., 1982). There was a positive significant relationship between dry sediment density and $\tau_{\mathrm{cr}}$ (log transformed) at stations $2-3\left(r^{2}=0.62 ; F_{1,12}=6.84 ; p=0.02\right)$. However, station 1 results deviated from this relationship for both the winter and the spring sampling periods. Here, sediments had a lower water content relative to the other two stations due most probably to their degree of compaction and prolonged emersion period. There was no significant relationship when station 1 data were included $\left(r^{2}=0.01 ; F_{1,14}=0.07 ; p=0.79\right)$.

The occurrence of $S$. plana was restricted largely to the upper parts of the mudflat (Table 2 and Table 3). The siphonal activity of S. plana creates wide, star-shaped holes at the entrance of the 
burrows and expels a considerable amount of pseudofaeces (Orvain, 2005). The results showed that the observed pattern of critical thresholds at station 1 was affected drastically by the bioturbation activities of $S$. plana.

Net bed erosion rates varied between 0.03 and $0.32 \mathrm{~g} \mathrm{~m}^{-2} \mathrm{~s}^{-1}$. Note that no relationship was found between erosion rate and the other variables, and there was no clear trend in the evolution of erosion rate during low tide (Table 1). Note also that before the main bed erosion phase, the fluff layer was eroded with rates that varied between 0.003 and $0.09 \mathrm{~g} \mathrm{~m}-2 \mathrm{~s}-1$. In this case, erosion rate was correlated with $\mathrm{H}$. ulvae biomass ( $\mathrm{r} 2=0.59$; $F 1,15=21.4 ; p<0.001$; Fig. $8 \mathrm{~A}$ ). Accordingly, a significant relationship was also found between $\mathrm{H}$. ulvae biomass and the mass of eroded sediment, at $20 \mathrm{~cm} \mathrm{~s}^{-1}$ (Fig. 8B). The critical shear stress for fluff layer erosion was $0.24 \pm 0.18 \mathrm{~Pa}$.

3.4. Surface chl a resuspension

For most of the time, chl a: SPM ratios in the water column averaged $500 \mu \mathrm{g} \mathrm{g}-1$ (Table 1), an order of magnitude greater than in the sediments. The relationship between chl a and SPM (Fig. 9; Table 1) changed as erosion progressed, reflecting vertical changes in the underlying sediments, and highlighting the change from fluff layer to bed erosion. Dividing the data into two groups, ratios calculated during fluff layer erosion (i.e. when the bed shear stress was between $\sigma_{\text {fluff }}$ and $\sigma_{\mathrm{cr}}$ ) were systematically higher than ratios calculated during the bed erosion phase (when the bed shear stress was higher than ocr; Table 1).

$\mathrm{Chl}$ a resuspension during fluff layer erosion was influenced by $H$. ulvae biomass. Chl a: SPM ratios showed a relationship with this variable, but the scatter was higher than for erosion rates and the relationship was not linear but quadratic $\left(r^{2}=0.36 ; F_{1,13}=7.45 ; p=0.017\right)$. A strong increase in the ratios versus $\mathrm{H}$. ulvae biomass was followed by a reduction in the rate of increase of ratios (Fig. 10). There was no correlation with other variables, to explain chl a resuspension during fluff layer erosion. Again, chl a present in the water column must have reflected the chl a content in the sediment close to the surface, however chl a biomass was not measured with a fine vertical resolution. When the biomass of $H$. ulvae was high, the ratios decreased, suggesting a trade-off between $H$. ulvae effects, which could stimulate and/or inhibit chl a enrichment at surface. When $H$. ulvae biomass was low, stimulating effects seemed to be higher than inhibiting effects. Alternatively, inhibiting effects must be greater than stimulating effects for higher $H$. ulvae biomass. This gastropod was the dominant species only on some occasions (runnels at stations 2-3 in November 2000, and ridges at station 2 in May 2001), but was the only species for which an effect on chl a resuspension could be identified. The second set of ratio values (during the bed erosion phase) was also considerably higher than pigment content in the uppermost $1 \mathrm{~cm}$, but was not related to macrofaunal biomass. These ratios showed non-linear trends as a function of pigment content (Fig. 10 and Fig. 11). In November 2000, an increase in the ratio with pigment content between 0 and $1 \mathrm{~cm}$ (chl a and phaeopigments) was obtained when this variable was included (in the range of 10-18 $\mathrm{\mu g} \mathrm{g}^{-1}$ ). For higher pigment content values, one observation also showed an increase (ratio value $>1400 \mathrm{\mu g} \mathrm{g}^{-1}$ ), whilst the other observation showed a reduction (ratio value of $507 \mathrm{\mu g} \mathrm{g}^{-1}$ ). In May 2001, low ratio values were obtained with a slight increase followed by a reduction, in the interval of $10-20 \mu \mathrm{g} \mathrm{g}^{-1}$. For a pigment content of $>20 \mu \mathrm{g} \mathrm{g}^{-1}$, one observation (with the highest sediment pigment content) showed a very high ratio increase $\left(809 \mathrm{\mu g} \mathrm{g}^{-1}\right)$, whilst another gave a value of $372 \mu \mathrm{g} \mathrm{g}^{-1}$.

\section{Discussion}

\subsection{The absence of microphytobenthic effects}

The comparison between dry sediment density depth profiles at the beginning and end of the emersion periods (Fig. 4) indicated that drainage and desiccation were important factors in governing sedimentary processes. Dry density in the uppermost sections always increased during spring in response to high solar exposure (Figs. 4B, D and F). Depth profiles of dry density on the ridge tops also reflected a solar-exposure mediated response during winter, since the dry density 
of the uppermost sections increased (Figs. 4C and E). In contrast, fresh deposits that accumulated in runnels remained covered by running water during the entire low-tide period and there was a decrease in dry density during winter (Figs. 4B and 4E). A similar trend was observed on irregular structures at station 1 during winter, due to resurgence of fresh water and drainage of sediments on the upper mudflat (Fig. 4A). The considerable variations in the critical erosion shear stresses of the mudflat sediments are attributed to the differences in sediment density (i.e. water content) due to desiccation, aerial exposure and drainage.

High chl a biomass was measured in May 2001. High spring chl a biomass, and low winter values, were also obtained by Guarini et al. (1998). A significant amount of EPS is produced in both seasons, with a greater extent in May 2001 (Table 1). Carbohydrate production has also been linked to processes of primary productivity (Staats et al., 2000; de Brouwer and Stal, 2001; Smith and Underwood, 2000; Orvain et al., 2003a). Consistent with the observations made in other studies, there was a weak relationship between chl a and LMW carbohydrates (Underwood et al., 1995; Galois et al., 2000; de Brouwer and Stal, 2001; Orvain et al., 2003a), however, this relationship was not significant in terms of production. Production rates of LMW carbohydrates are described usually as positively correlated with chl a production (Smith and Underwood, 2000; Orvain et al., 2003a). In the present study, there was no relationship between EPS and chl a in terms of biomass, but a strong negative correlation in terms of production (Fig. 5B). The findings of Staats et al. (2000) and Orvain et al., 2003a and Orvain et al., 2004 described low production rates of EPS during exponential growth, whilst production of EPS is stimulated during stationary growth if the latter is caused by nutrient limitation. The two different relations that we have found can be interpreted in the light of the recent findings on the different metabolic pathways of diatoms, by which photosynthetically assimilated carbon can be involved in LMW carbohydrates and EPS (Underwood et al., 2004). EPS production is not coupled directly to the photosynthetic production of carbohydrates. There is a direct pathway between photosynthetically assimilated carbon and LMW carbohydrates (non-polymeric) and another route, by which the carbon is stored in glucans which can be then used for EPS synthesis during periods of darkness.

Even if a relationship between chl $a$ and colloidal carbohydrate fractions can be found, our results show that the microphytobenthos does not affect the critical shear stress for bed erosion. Blanchard et al. (2000) assumed that any potential effects of biostabilisation would be negligible in runnels, because these structures remain covered by running water even at low tide. These authors reported that colloidal carbohydrate values remained low in runnels because they were flushed continuously by water draining off the mudflat. Release of colloidal carbohydrate into the water column was also observed by Orvain et al. (2003a) in laboratory experiments. Amos et al. (1988) and Mitchener and O'Brien (2001) found major roles for sediment density and minor roles for microphytobenthos on bed stability.

Biostabilisation has been demonstrated in field studies (Paterson, 1989; Sutherland et al., 1998; Paterson and Black, 1999; Smith and Underwood, 2000; Friend et al., 2003). However, we suggest that on the mudflats of the Marennes-Oléron Bay, chl a and/or the two carbohydrate fractions (LMW carbohydrate and EPS) are not relevant variables in predicting bed erodability. Any role of EPS in stabilisation would be limited to the ridge tops, where desiccation and drainage processes may affect the properties of the diatom mats. The relationship between chl $a$ and bed stability found in other systems does not necessarily mean that microphytobenthic development is the primary cause of sediment stabilisation. For example, desiccation and growth may be interrelated because they both are dependent upon temperature and light. Similarly, the development of microphytobenthos is favoured when the mud content is high and when the hydrodynamic conditions are calm.

\subsection{Macrofauna effects on bed erodability}

Natural sediment beds have irregular surfaces that affect the bed roughness at a local scale. Macrofaunal activity is responsible for enhancing bed roughness at a microscale (Wright et al., 1997). Consequently, smooth turbulent flow becomes rough turbulent flow in response to, for example, tracks, holes, mounts, and shell fragments. In the present study, variations in bed roughness between the beginning and end of the emersion period can be attributed to the 
presence of $H$. ulvae shells and/or S. plana pseudofaecal mounts. These effects have important implications for the sediment budget of an ecosystem since an increase in bed roughness suggests that consolidated beds are available for erosion. The threshold effects of the bioturbation remain to be quantified before they can be included into spatial models.

A laboratory study on the effect of S. plana (Orvain, 2005) has shown that the critical threshold for bed erosion decreases drastically with the density of $\mathrm{S}$. plana. This biological influence induces the absence of a relationship between critical erosion threshold and sediment dry density on the upper shore (Fig. 7). The desiccated surficial sediments at station 1 have very low critical thresholds, whilst their dry densities are relatively high. On the Marennes-Oléron mudflats, the effect of S. plana is extremely high on the upper shore (station 1), where very high biomasses of this dominant species are reached. The present study shows clearly that the sediments inhabited by very dense populations of S. plana are characterised by very low critical thresholds for bed erosion. This effect has important consequences in terms of sediment dynamics, especially on the upper mudflats. A similar investigation by Wood and Widdows (2002) in the Humber Estuary, UK, found that bioturbation activities (due to $M$. balthica) are one of the primary factors in regulating sediment dynamics and mudflat morphology. The present study demonstrates the necessity of including the effects of $S$. plana on the critical shear stress for bed erosion in spatial models of sediment erosion and transport.

The intense feeding activities of $S$. plana during low-tide periods also produce copious amounts of reworked sediment, often covering the sediment surface with pseudofaecal mounts up to $2 \mathrm{~cm}$ high. The production of such a fluff layer has been demonstrated to affect erosion features for $M$. balthica (Willows et al., 1998) and for S. plana (Orvain, 2005). As the bed erosion occurred very soon during erosion experiments at station 1, the fluff layer erosion was much reduced, and the potential effects of bivalves on erosion rates during fluff layer erosion could not be determined. Only an influence of $H$. ulvae was found on erosion rates during fluff layer erosion. The lack of bivalve effects on this parameter (even at station 1) is related probably to their high influence exerted on bed erosion. Indeed, bed erosion occurred so soon during erosion experiments at station 1 that the duration of fluff layer erosion was extremely short. In these circumstances, the eroded biodeposits produced by bivalves must be included in resuspended material during bed erosion. However, no relationship was found between erosion rates and bivalve biomass.

There is laboratory evidence for the influence of $H$. ulvae populations on the enhancement of sediment erodability (Orvain and Sauriau, 2002; Andersen et al., 2002). These laboratory studies have demonstrated that erosion rate (during fluff layer erosion) depends upon the density of the $H$. ulvae and upon bioturbation time, whilst the erosion threshold for biogenic fluff layer erosion is low and does not vary. The dependence of erosion rates upon snail biomass in the present study is consistent with this observation (Fig. 8). This is the only parameter that was correlated to erosion rates. The low values of the critical threshold for biogenic fluff layer erosion, and the low level of variability, are in agreement with laboratory findings (Willows et al., 1998; Andersen et al., 2002; Orvain et al., 2003a, Orvain et al., 2003b and Orvain et al., 2004; Orvain, 2005), and suggest that the potential increase in bed roughness due to snail tracks is negligible with respect to the ease of erosion of the material in the tracks. The strongest influence of $\mathrm{H}$. ulvae on bed roughness is most likely the presence of the snails themselves. In parallel studies, Orvain et al., 2003b and Orvain et al., 2004 have demonstrated that microphytobenthos biomass and dry sediment density exert a regulating influence on fluff layer formation by $\mathrm{H}$. ulvae, and therefore on erosion rates of the fluff layer. Such regulating effects exerted by other sediment parameters were not observed in the field, where the properties close to the sediment surface are very heterogeneous and should be measured on a very fine vertical scale.

The data set presented here was compared with eroded mass data computed by a model (Orvain et al., 2003b and Orvain et al., 2004) developed from laboratory data. In similar conditions (of both sediment and snail densities), the model underestimates the mass of sediment, which is resuspended during the fluff erosion phase. In the field, continuous sediment dynamics create a surface layer, which is likely to differ from the biogenic fluff layer formed by snails in a laboratory setting. In the laboratory, there were few faecal pellets in the resuspended material. In contrast, Andersen and Pejrup (2002) have found that faecal pellets originating from $\mathrm{H}$. ulvae, can form a substantial part of the suspended load at intertidal mudflats. Faecal pellets have a settling velocity an order of magnitude higher than their constituent particles, and they are redeposited on every 
tidal cycle until they break apart under the actions of tidal movements and bacterial degradation (Taghon et al., 1984). Thus, faecal pellets accumulate at the surface, where they can represent up to $25 \%$ of the bulk surface material (Andersen and Pejrup, 2002). The Polychaeta group is also well represented in the total macrofaunal biomass, but potential effects on bed erodibility are still unknown and should be studied in the future.

\subsection{Implication for microphytobenthic dynamics}

These observations of $\mathrm{chl}$ a resuspension emphasise that differences in the depth of sediment erosion must be considered in interpreting chl a resuspension and dynamics. Lucas et al. (2000) also found that changes in the pigment characteristics of the resuspended material reflect differences in the vertical repartition of micro-algae in the sediment. Interpreting the vertical micro-repartition of micro-phytobenthos is a task of increasing relevance (de Jonge and Colijn, 1994, Wiltshire et al., 1998; Guarini et al., 2000; Kelly et al., 2001) and the accumulation of chl a at the sediment-water interface is known to be controlled by the migratory rhythms of cells and the dynamics of primary production (Guarini et al., 2000). Microalgal standing stocks are also regulated by grazing (Haubois et al., 2005) and the surface tracks formed by $\mathrm{H}$. ulvae have been found to be microenvironments favouring the accumulation of chl a at the interface during laboratory studies (Blanchard et al., 1997; Orvain et al., 2004 and Orvain et al., 2006). It has been demonstrated clearly in these laboratory studies that bioturbation by $H$. ulvae plays a significant role in chl a resuspension.

Our results show that fluff layer erosion rates depend upon a single factor, the biomass of $H$. ulvae. Accordingly, the chl a: SPM ratio during fluff layer erosion also depends upon this factor, whereas there are no other variables that seem to affect these ratios. The relationship in question shows that activities of $\mathrm{H}$. ulvae can either stimulate or inhibit the accumulation of chl a at the sediment-water interface (Fig. 10). An increase of ratios as a function of $\mathrm{H}$. ulvae biomass was obtained when this parameter was included in a range of low values, and a decrease when shifting towards higher biomass values. The value for which maximum chl a resuspension is obtained is $\sim 3 \mathrm{~g}$ AFDW m-2 (Fig. 10). The interaction between two opposite actions seems to be accomplished by a trade-off between one stimulatory process and one inhibitory effect. The increase of chl a: SPM is comparable to the effect found by Blanchard et al. (1997) and Orvain et al., 2004 and Orvain et al., 2006 in which it was shown that bioturbation by snails enhances pigment resuspension. On the other hand, the decrease can be explained by a grazing pressure exerted by the snail. Both processes are density-dependent, but do not seem to follow the same pattern as a function of snail density.

Even if $H$. ulvae is not dominant in terms of biomass, and has a low impact on bed erodability compared to $S$. plana, this is the single macrofauna species that has been found to play a role in chl a resuspension. This observation can be explained by the different modes of feeding between both species. H. ulvae is a very mobile grazer that can select patches rich in microphytobenthos, whereas S. plana is sedentary and can only graze on the microphytobenthos in its immediate vicinity. In terms of coverage rate of a sedimentary surface, motile grazers such as $\mathrm{H}$. ulvae produce tracks that may progressively cover large surfaces of sediments (Orvain and Sauriau, 2002), and their crawling activities decrease when they encounter patches enriched in microphytobenthos (Forbes and Lopez, 1989). The behaviour of H. ulvae in terms of crawling and food acquisition can be interpreted by an optimal foraging strategy (Orvain and Sauriau, 2002). As a result, the surface area: height of the bioturbated layers is considerably higher for $\mathrm{H}$. ulvae than for S. plana. This may explain why $\mathrm{H}$. ulvae can potentially affect the environment of the microphytobenthos biofilm, whereas such an effect of Scrobicularia is restricted to the local area around the burrow.

\section{Conclusions}

The results of this field study are, for the most part, consistent with laboratory studies on the contribution of benthic organisms to sediment dynamics (Orvain and Sauriau, 2002; Orvain et al., 
2003a and Orvain et al., 2003b; Orvain, 2005). The deployment of the ERIS instrument at sites along a cross-shore transect on the Montportail-Brouages mudflat identified that: (1) bed erosion is controlled by changes in sediment dry density that may be influenced by desiccation processes at stations 2 and 3 on the mudflats; (2) S. plana bioturbation plays an additional role in bed erodability on the upper parts of the mudflat (station 1 ) by affecting the critical threshold for bed erosion; (3) H. ulvae bioturbation is the governing factor that can explain fluff layer resuspension before general bed erosion; (4) bioturbation activities of $H$. ulvae enhance chl a resuspension by increasing the quantity of microalgal cells when forming a fluff layer, but this mechanism seems to be reduced within dense populations of $H$. ulvae; and (5) the different microalgae indicators (chl a and carbohydrate fractions) do not appear relevant to bed erosion on the Marennes-Oléron Bay mudflats. However, chl a analysis must be performed on a very fine vertical scale to confirm this observation. This study reveals that, when attempting to establish a hierarchy in the processes related to the influence of deposit-feeders on sediment erosion at the water-sediment interface, the main effect that must be incorporated in models to evaluate sediment budget is the modification of bed erodability due to stationary deposit-feeder bivalves (such as S. plana), whereas the main effect that must be incorporated in a model describing microphytobenthos resuspension is the formation of a fluff layer at the surface by a mobile grazer (such as $H$. ulvae), and the potential enrichment of this sediment matrix with microphytobenthos.

\section{Acknowledgements}

The Regional Council of Poitou-Charente and IFREMER have supported the study through a doctoral grant awarded to F. Orvain. We are grateful to L. Joassard for assistance in the lab and J. Guarini for improving the English language. We are considerably indebted to the 2 referees for their constructive comments.

\section{References}

Amos et al., 1988 C.L. Amos, N.A. van Wagoner and G.R. Daborn, The influence of subaerial exposure on the bulk properties of fine-grained intertidal sediment from Minas Basin, Bay of Fundy, Estuarine, Coastal and Shelf Science 27 (1988), pp. 1-13.

Andersen, 2001 T.J. Andersen, Seasonal variation in erodability of two temperate, microtidal mudflats, Estuarine, Coastal and Shelf Science 53 (2001), pp. 1-12.

Andersen, 2002 T.J. Andersen, K.T. Jensen, L. Lund-Hansen, K.N. Mouritsen and M. Pejrup, Enhanced erodability of fine-grained marine sediments by Hydrobia ulvae, Journal of Sea Research 48 (2002), pp. 51-58.

Andersen and Pejrup, 2002 T.J. Andersen and M. Pejrup, Biological mediation of the settling velocity of bed material eroded from an intertidal mudflat, the Danish Wadden Sea, Estuarine, Coastal and Shelf Science 54 (2002), pp. 737-745.

Blanchard et al., 1997 G.F. Blanchard, P.-G. Sauriau, V. Cariou-Le Gall, D. Gouleau, M.J. Garet and $F$. Olivier, Kinetics of tidal resuspension of microbiota: testing the effects of sediment cohesiveness and bioturbation using flume experiments, Marine Ecology Progress Series 151 (1997), pp. 17-25.

Blanchard et al., 2000 G.F. Blanchard, D.M. Paterson, L.J. Stal, P. Richard, R. Galois, V. Huet, J. Kelly, C. Honeywill, J. de Brouwer, K. Dyer, M. Christie and M. Seguignes, The effect of geomorphological structures on potential biostabilisation by microphytobenthos on intertidal mudflats, Continental Shelf Research 20 (2000), pp. 1243-1256. 
de Brouwer and Stal, 2001 J.F.C. de Brouwer and L.J. Stal, Short-term dynamics in microphytobenthos distribution and associated extracellular carbohydrates in surface sediments of an intertidal mudflat, Marine Ecology Progress Series 218 (2001), pp. 33-44.

de Jonge and Colijn, 1994 V.N. de Jonge and F. Colijn, Dynamics of microphytobenthos biomass in the ms estuary, Marine Ecological Progress Series 104 (1994), pp. 185-196.

Dubois et al., 1956 M. Dubois, K.A. Gilles, J.K. Hamilton, P.A. Rebers and F. Smith, Colorimetric method for determination of sugars and related substances, Analytical Chemistry 28 (1956), pp. 350-356.

Dyer et al., 2000 K.R. Dyer, M.C. Christie and E.W. Wright, The classification of intertidal mudflats, Continental Shelf Research 20 (2000), pp. 1039-1060.

Forbes and Lopez, 1989 V.E. Forbes and G. Lopez, The role of sediment particle size in the nutritional energetics of a surface deposit-feeder. I. Ingestion and absorption of sedimentary microalgae by Hydrobia truncata (Vanatta), Journal of Experimental Marine Biology and Ecology 126 (1989), pp. 181-192.

Friend et al., 2003 P.L. Friend, P. Ciavola, S. Cappucci and R. Santos, Bio-dependent bed parameters as a proxy tool for sediment stability in mixed habitat intertidal areas, Continental Shelf Research 23 (2003), pp. 1899-1917.

Galois et al., 2000 R. Galois, G. Blanchard, M. Seguignes, V. Huet and L. Joassard, Spatial distribution of sediment particulate organic matter on two estuarine mudflats: a comparison between Marennes-Oléron Bay (France) and the Humber Estuary (UK), Continental Shelf Research 20 (2000), pp. 1199-1217.

Gouleau et al., 2000 D. Gouleau, J.M. Jouanneau, O. Weber and P.-G. Sauriau, Short- and longterm sedimentation on Montportail-Brouage intertidal mudflat, Marennes-Oléron Bay (France), Continental Shelf Research 20 (2000), pp. 1513-1530.

Grant and Daborn, 1994 J. Grant and G. Daborn, The effects of bioturbation on sediment transport on an intertidal mudflat, Netherlands Journal of Sea Research 32 (1994), pp. 63-72.

Guarini et al., 1998 J.-M. Guarini, G.F. Blanchard, C. Bacher, P. Gros, P. Riéra, P. Richard, D. Gouleau, R. Galois, J. Prou and P.-G. Sauriau, Dynamics of spatial patterns of microphytobenthic biomass: inferences from a geostatistical analysis of two comprehensive surveys in MarennesOléron Bay (France), Marine Ecology Progress Series 166 (1998), pp. 131-141.

Guarini et al., 2000 J.-M. Guarini, G.F. Blanchard, P. Gros, D. Gouleau and C. Bacher, Dynamic model of the short-term variability of microphytobenthos biomass on temperate intertidal mudflats, Marine Ecology Progress Series 195 (2000), pp. 291-303.

Haubois et al., 2005 A.-G. Haubois, J.-M. Guarini, P. Richard, D. Fichet, G. Radenac and G.F. Blanchard, Ingestion rate of the deposit-feeder Hydrobia ulvae (Gastropoda) on epipelic diatoms: effects of cell size and algal biomass, Journal of Experimental Marine Biology and Ecology 317 (2005), pp. 1-12.

Kelly et al., 2001 J.A. Kelly, C. Honeywill and D.M. Paterson, Microscale analysis of chlorophyll-a in cohesive, intertidal sediments: the implications of microphytobenthos distribution, Journal of Marine Biology Association UK 81 (2001), pp. 151-162.

Lorenzen, 1966 C.J. Lorenzen, A method for the continuous measurement of in vivo chl concentration, Deep Sea Research 13 (1966), pp. 223-227. 
Lucas et al., 2000 C.H. Lucas, J. Widdows, M.D. Brinsley, P.N. Salkeld and P.M.J. Herman, Benthic-pelagic exchange of microalgae at a tidal flat. 1. Pigment analysis, Marine Ecology Progress Series 196 (2000), pp. 59-73.

Mehta et al., 1982 A.J. Mehta, T.M. Parchure, J.G. Dixit and R. Ariathurai., Resuspension potential of deposited beds. In: V.S. Kennedy, Editor, Estuarine Comparisons, Academic Press, Florida (1982), p. 709.

Migniot, 1968 C. Migniot, Etude des propriétés physiques de différents sédiments très fins et de leur comportement sous des actions hydrodynamiques, La Houille Blanche 7 (1968), pp. 591620.

Mitchener and O'Brien, 2001 H.J. Mitchener and D.J. O'Brien, Seasonal variability of sediment erodability and properties on a macrotidal mudflat, Peterstone Wentlooge, Severn Estuary, UK. In: W.H. McAnally and A.J. Mehta, Editors, Coastal and Estuarine Fine Sediment Processes, Elsevier Science B.V. (2001), pp. 301-322.

Nowell et al., 1981 A.R.M. Nowell, P.A. Jumars and J.E. Eckman, Effects of biological activity on the entrainment of marine sediments, Marine Geology 42 (1981), pp. 133-153.

Orvain, 2005 F. Orvain, A model of sediment transport under the influence of bioturbation activities: generalisation to a key-species Scrobicularia plana, Marine Ecology Progress Series 286 (2005), pp. 43-56.

Orvain and Sauriau, 2002 F. Orvain and P.-G. Sauriau, Environmental and behavioural factors affecting bioturbation activities in the intertidal gastropod Hydrobia ulvae, Journal of Experimental Marine Biology and Ecology 272 (2002), pp. 191-216.

Orvain et al., 2003a F. Orvain, R. Galois, C. Barnard, A. Sylvestre, G. Blanchard and P.G. Sauriau, Carbohydrate production in relation to microphytobenthic biofilm development: an integrated approach in a tidal mesocosm, Microbial Ecology 45 (2003), pp. 237-251.

Orvain et al., 2003b F. Orvain, P. Le Hir and P.G. Sauriau, A model of fluff layer and subsequent bed erosion in the presence of the bioturbator, Hydrobia ulvae, Journal of Marine Research $\mathbf{6 1}$ (2003), pp. 823-851.

Orvain et al., 2004 F. Orvain, P.-G. Sauriau, A. Sygut, L. Joassard and P. Le Hir, Interacting effects of Hydrobia ulvae bioturbation and microphytobenthos on the erodability, Marine Ecology Progress Series 278 (2004), pp. 205-233.

Orvain et al., 2006 F. Orvain, P.-G. Sauriau, C. Bacher and M. Prineau, The influence of sediment cohesiveness on bioturbation effects due to Hydrobia ulvae on the initial erosion of intertidal sediments: a study combining flume and model approaches, Journal of Sea Research 55 (2006), pp. 54-73.

Paterson, 1989 D.M. Paterson, Short-term changes in the erodability of intertidal cohesive sediments related to the migratory behavior of epipelic diatoms, Limnology and Oceanography 34 (1989), pp. 223-234.

Paterson and Black, 1999 D.M. Paterson and K.S. Black, Water flow, sediment dynamics and benthic biology, Advances in Ecological Research 29 (1999), pp. 155-193.

Rhoads and Young, 1970 D.C. Rhoads and D.K. Young, The influence of deposit-feeding organisms on sediment stability and community trophic structure, Journal of Marine Research $\mathbf{2 8}$ (1970), pp. 150-178. 
Shimeta et al., 2002 J. Shimeta, C.L. Amos, S.E. Beaulieu and O.M. Ashiru, Sequential resuspension of protists by accelerating tidal flow: implications for community structure in the benthic boundary layer, Limnology and Oceanography 47 (2002), pp. 1152-1164.

Smith and Underwood, 2000 D.J. Smith and G.J.C. Underwood, The production of extracellular carbohydrates by estuarine benthic diatoms, the effects of growth phase and light and dark treatment, Journal of Phycology 36 (2000), pp. 321-333.

Staats et al., 2000 N. Staats, L.J. Stal and L.R. Mur, Exopolysaccharide production by the epipelic diatom Cylindrotheca closterium: effects of nutrient conditions, Journal of Experimental Marine Biology and Ecology 249 (2000), pp. 13-27.

Sutherland, 1998 T.F. Sutherland, C.L. Amos and J. Grant, The effect of buoyant biofilms on the erodibility of sublittoral sediments of a temperate microtidal estuary, Limnology and Oceanography 43 (1998), pp. 225-235.

Taghon et al., 1984 G.L. Taghon, A.R.M. Nowell and P.A. Jumars, Transport and breakdown of fecal pellets: biological and sedimentological consequences, Limnology and Oceanography 29 (1984), pp. 64-72.

Underwood et al., 1995 G.J.C. Underwood, D.M. Paterson and R.J. Parkes, The measurement of microbial carbohydrate exopolymers from intertidal sediments, Limnology and Oceanography $\mathbf{4 0}$ (1995), pp. 1243-1253.

Underwood et al., 2004 G.J.C. Underwood, M. Boulcott, C.A. Raines and K. Waldron, Environmental effects on exopolymer production by marine benthic diatoms: dynamics in composition, and pathways of production, Journal of Phycology 40 (2004), pp. 293-304.

Widdows et al., 2000 J. Widdows, S. Brown, M.D. Brown, M.D. Brinsley, P.N. Salkeld and M. Elliott, Temporal changes in intertidal sediment erodability: influence of biological and climatic factors, Continental Shelf Research 20 (2000), pp. 1275-1289.

Willows et al., 1998 R.I. Willows, J. Widdows and R.G. Wood, Influence of an infaunal bivalve on the erosion of an intertidal cohesive sediment: a flume and modeling study, Limnology and Oceanography 43 (1998), pp. 1332-1343.

Wiltshire et al., 1998 K.H. Wiltshire, T. Tolhurst, D.M. Paterson, I. Davidson and G. Gust, Pigment fingerprints as markers of erosion and changes in cohesive sediment surface properties in simulated and natural erosion events. In: K.S. Black, D.M. Paterson and A. Cramp, Editors, Sedimentary Processes in the Intertidal Zone, Special Publication, London Geological Society (1998), p. 409.

Wood and Widdows, 2002 R. Wood and J. Widdows, A model of sediment transport over an intertidal transect, comparing the influences of biological and physical factors, Limnology and Oceanography 47 (2002), pp. 848-855.

Wright et al., 1997 L.D. Wright, L.C. Schaffner and J.P.Y. Maa, Biological mediation of bottom boundary layer processes and sediment suspension in the lower Chesapeake Bay, Marine Geology 141 (1997), pp. 27-50. 


\section{Figures}

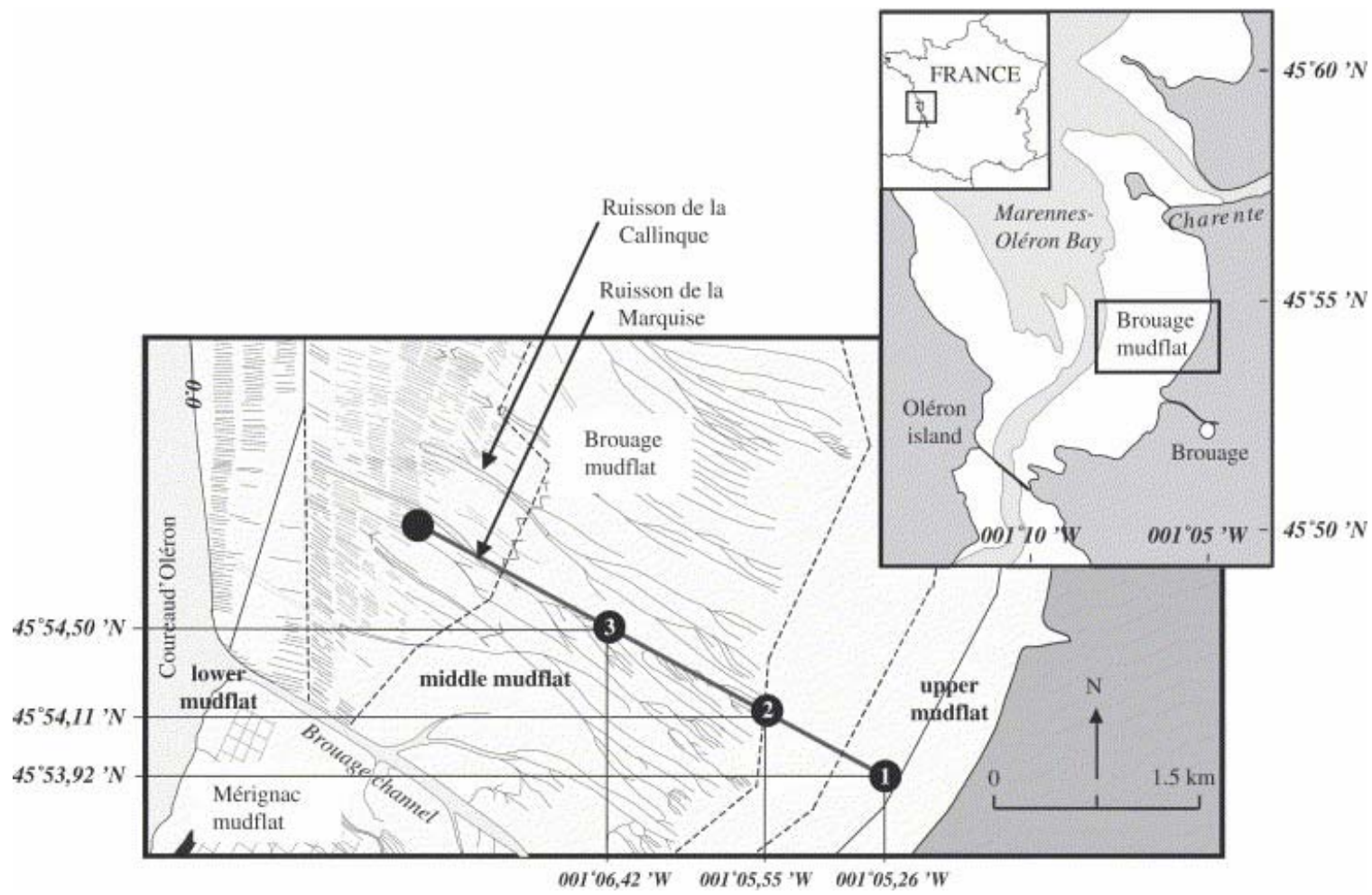

Fig. 1. Location map of the Montportail-Brouages mudflat in the Marennes-Oléron Bay, western France. Sites 1, 2 and 3 on the cross-shore transect where erosion experiments were made during November 2000 and May 2001 are indicated on the inset.

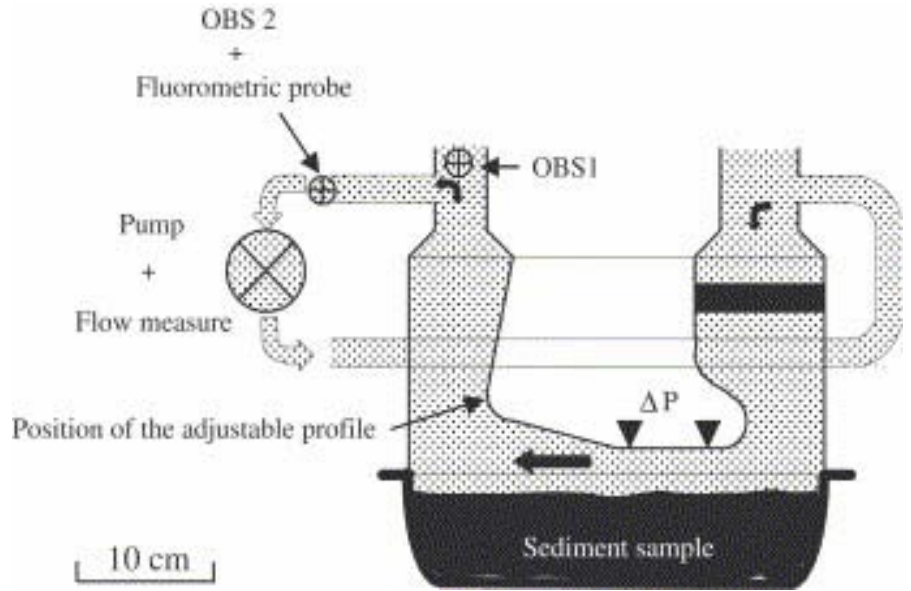

Fig. 2. Schematic representation of the portable eroding device (ERIS-Version 2) showing: the sampling unit and the eroding unit, which is connected to a pump; the placement of the two OBSs; and fluorometric probe. The profile is adjusted to achieve a constant gap of $2 \mathrm{~cm}$. The difference in pressure, $\Delta P$, is measured over a sub-area of the sediment sample. 
A

Soft or destabilised sediments (station 1 and runnels of stations 2-3)

Runnel - Station 2 - End of low tide - November 2000
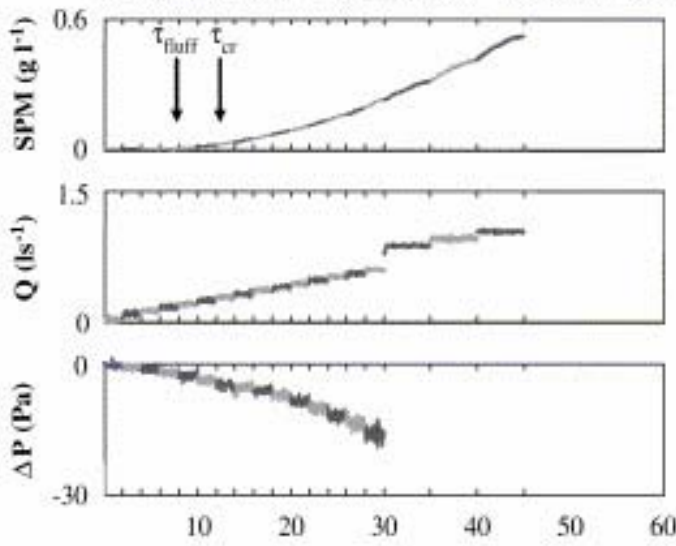

C
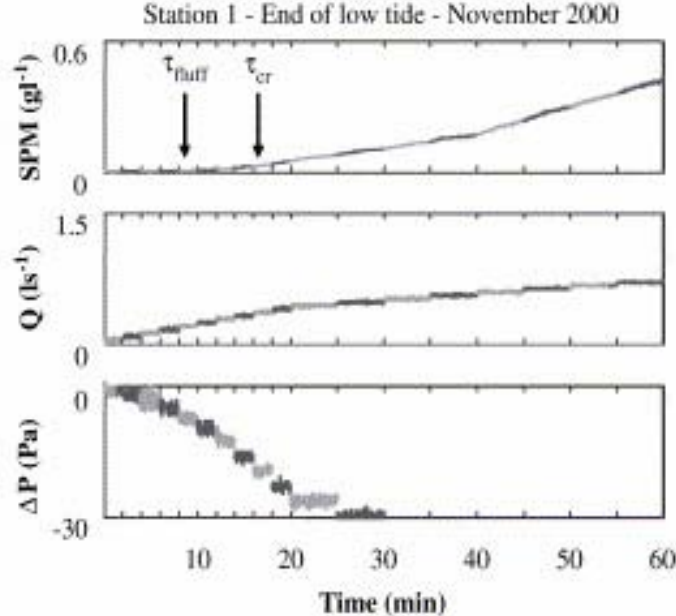

B

Ridges (ridges of stations 2-3)

Ridge - Station 2 - Beginning of low tide - November 2000
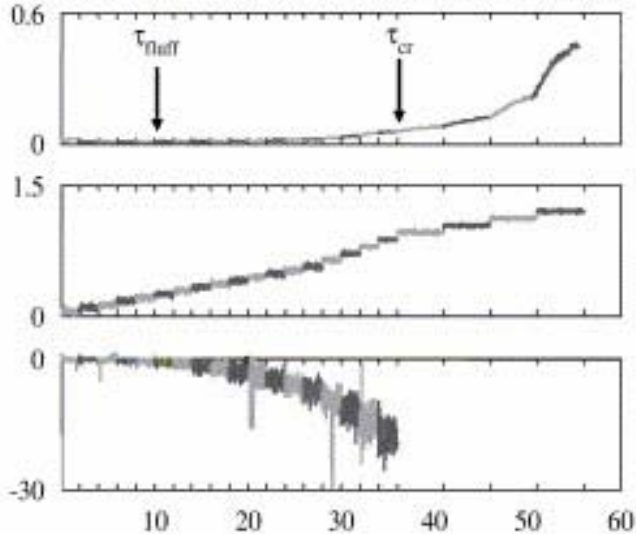

D

Ridge - Station 3 - End of low tide - November 2000
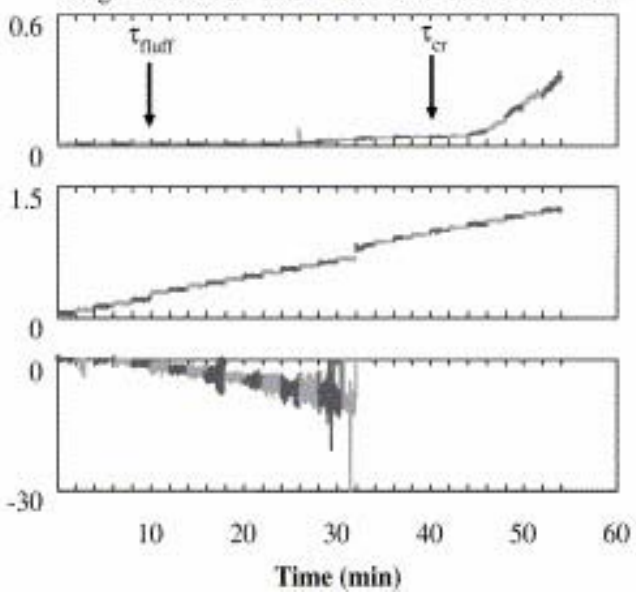

Fig. 3. Four time series of SPM, flow discharge, and difference in pressure $\Delta P$ in the eroding device during deployments. Two typical illustrations of soft sediments $(A, C)$, and two typical illustrations of consolidated sediments (B,D) are shown. 
A
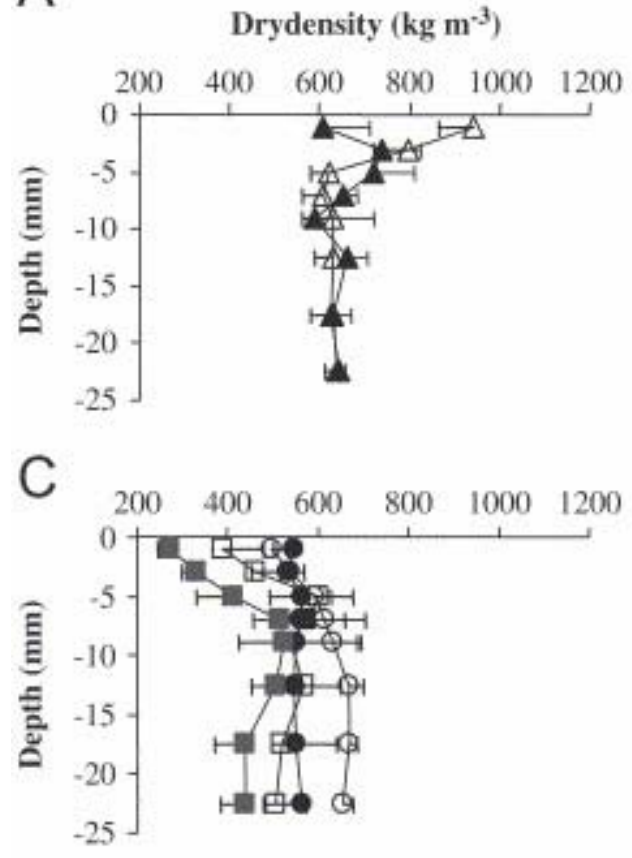

$E$

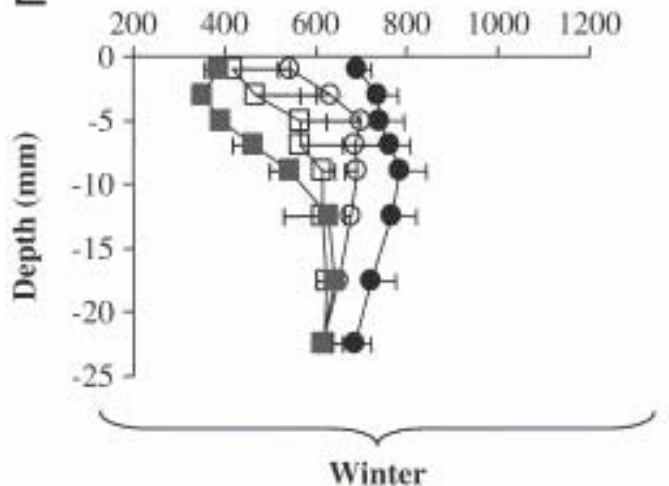

B
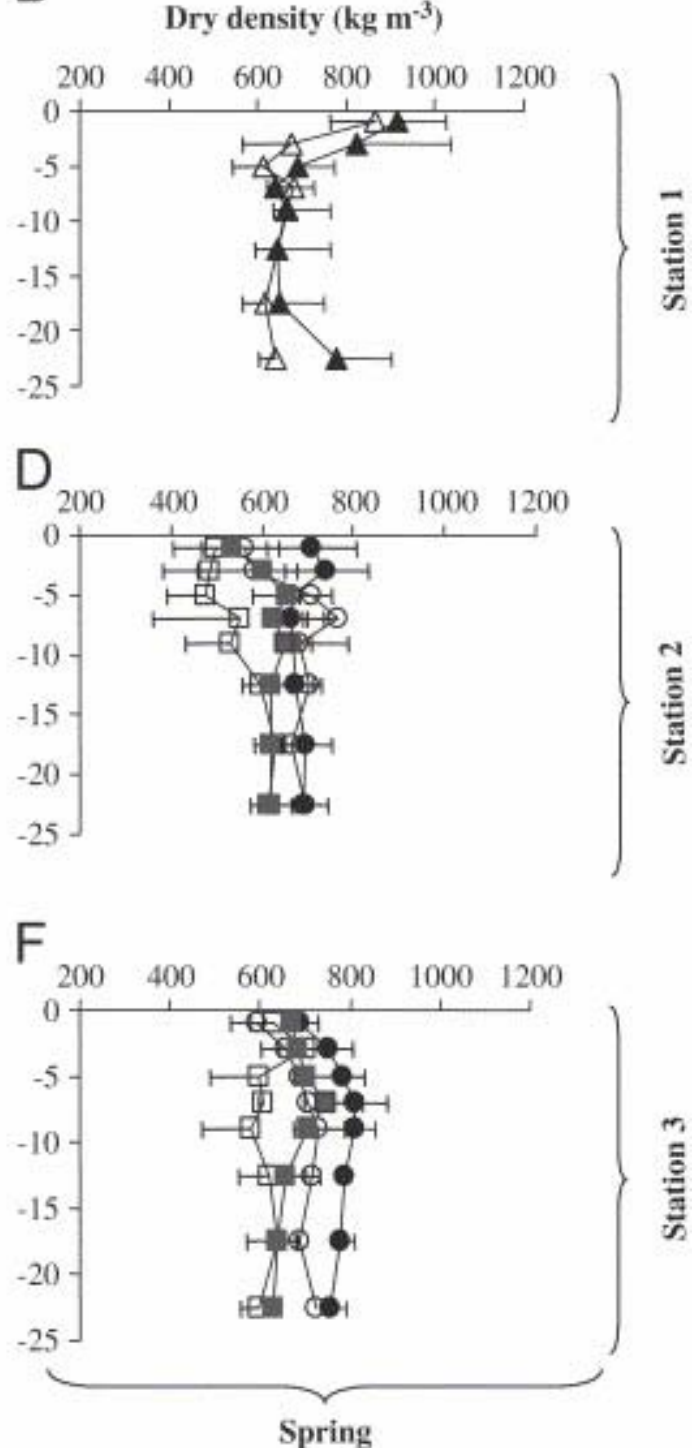

Station 1: $\Delta$ Criss-cross pseudo-ripples-Beginning of the low-tide

A Criss-cross pseudo-ripples-End of the low-tide

Station 2-3: 0 Ridge-Beginning of the low tide

ㅁ Runnel-Beginning of the low tide
- Ridge-End of the low tide

- Runnel-End of the low tide

Fig. 4. Depth profiles of sediment dry density in the uppermost $25 \mathrm{~mm}$. Horizontal bars denote the standard deviation of dry densities at each level $(n=5)$. Data are grouped according to the beginning and the end of emersion station, geomorphologic structure and sampling period: $(A)$ station 1-November 2000; (B) station 1-May 2001; (C) station 2-November 2000; (D) station 2-May 2001; (E) station 3-November 2000; and (F) station 3-May 2001. 

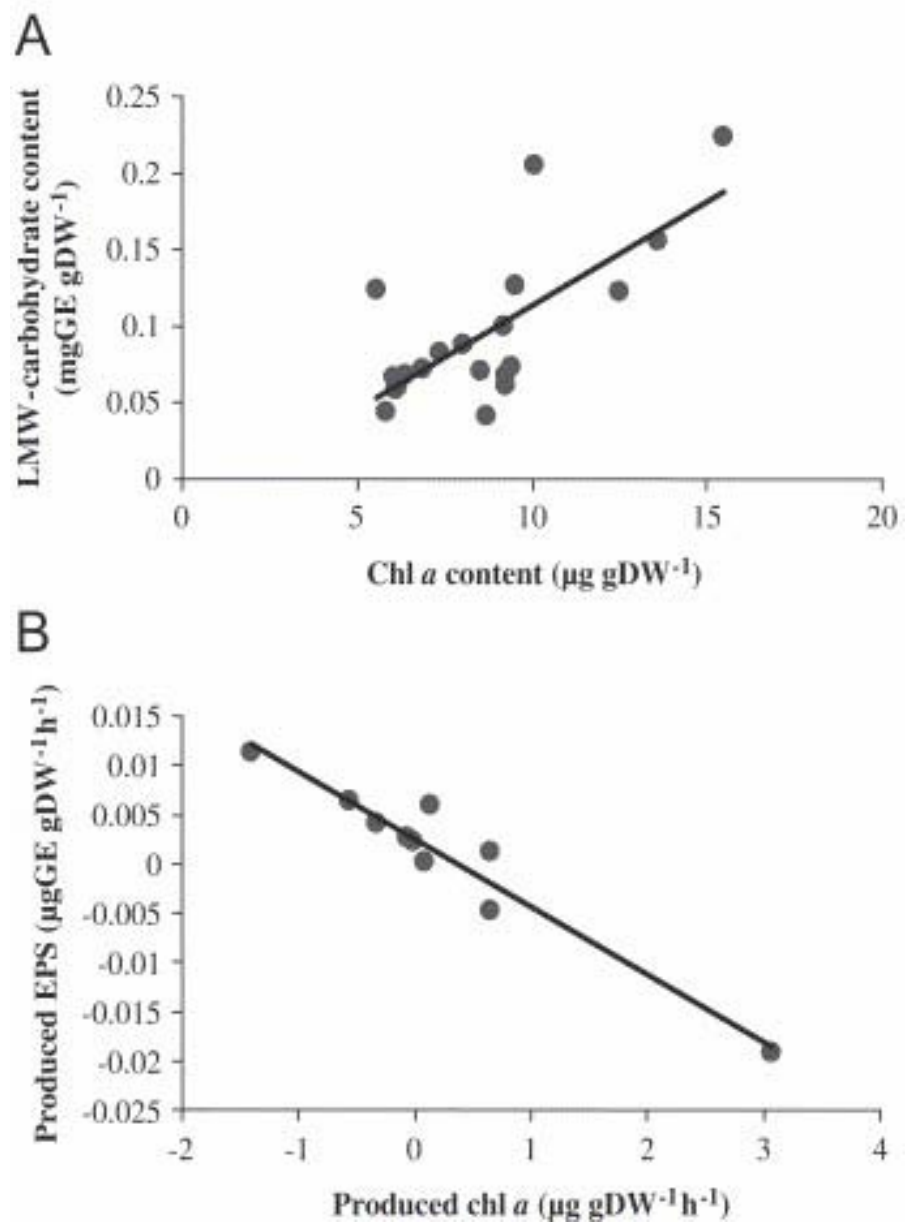

Fig. 5. Scatterplots of: (A) LMW carbohydrate content as a function of chl a content and (B) produced EPS as a function of produced chl a. Regressions were established based on the means $(n=5)$. The linear regression equations are: (A) [soluble-EPS] $=0.014 \times[\mathrm{chl} a]-0.02$ $\left(r^{2}=0.52 ; p<0.001\right)$ and $(\mathrm{B})$ [produced bound-EPS] $=-0.006 \times$ [produced $\left.\mathrm{chl} a\right]\left(r^{2}=0.84 ; p<0.001\right)$. 


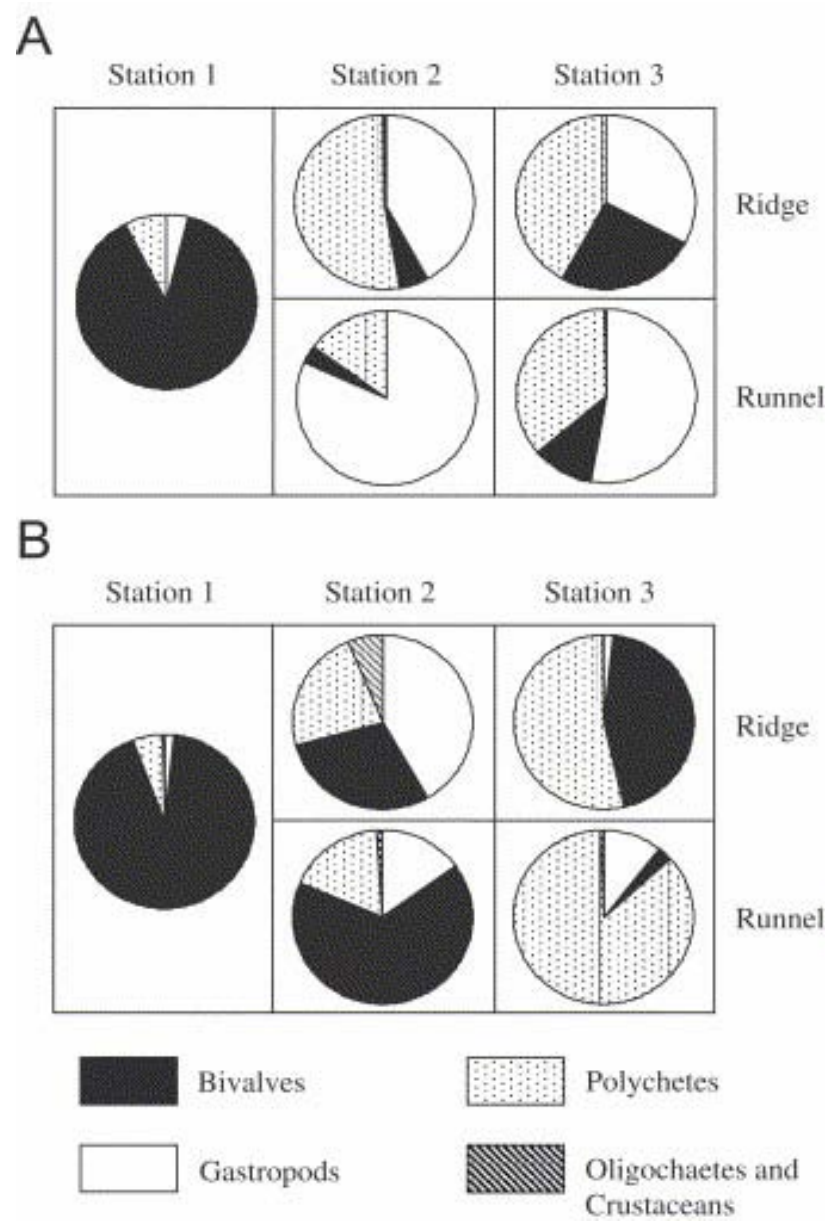

Fig. 6. Contribution of all groups to the total macrofauna biomass in November 2000 (A) and May 2001 (B). Oligochaetes and Crustaceans are combined because their biomass was low and their contribution is not apparent on the diagram when taken separately.

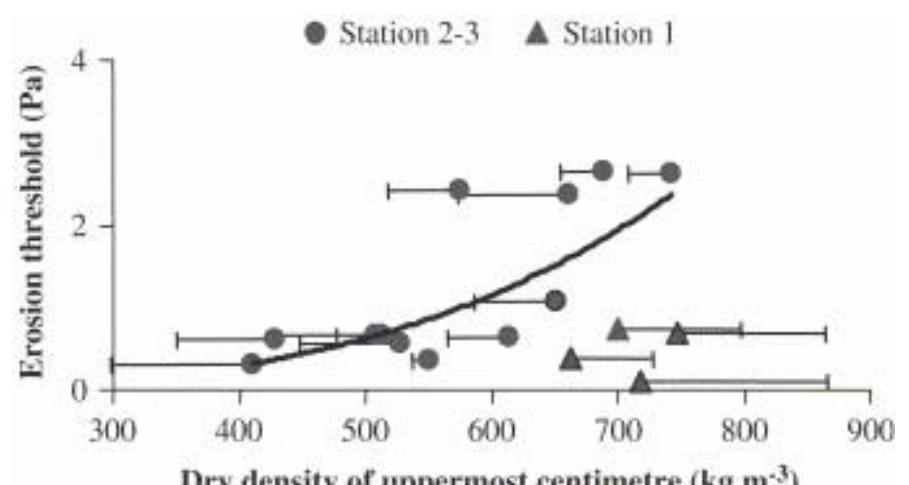

Fig. 7. Scatterplot of erosion threshold, $T_{\mathrm{cr}}$, against sediment density. A significant power law was obtained when pooling data from stations 1 and $2\left(I_{\mathrm{cr}}=4.79 \times 10^{-10} \times \rho_{\mathrm{d}}{ }^{3.36} ; r^{2}=0.62 ; F_{1,12}=6.84\right.$; $p=0.023$ ). Station 1 results deviated from the pattern observed at stations 2 and 3 . The inclusion of station 1 data shows that the dry density is not the sole parameter explaining the critical shear stress for bed erosion. 

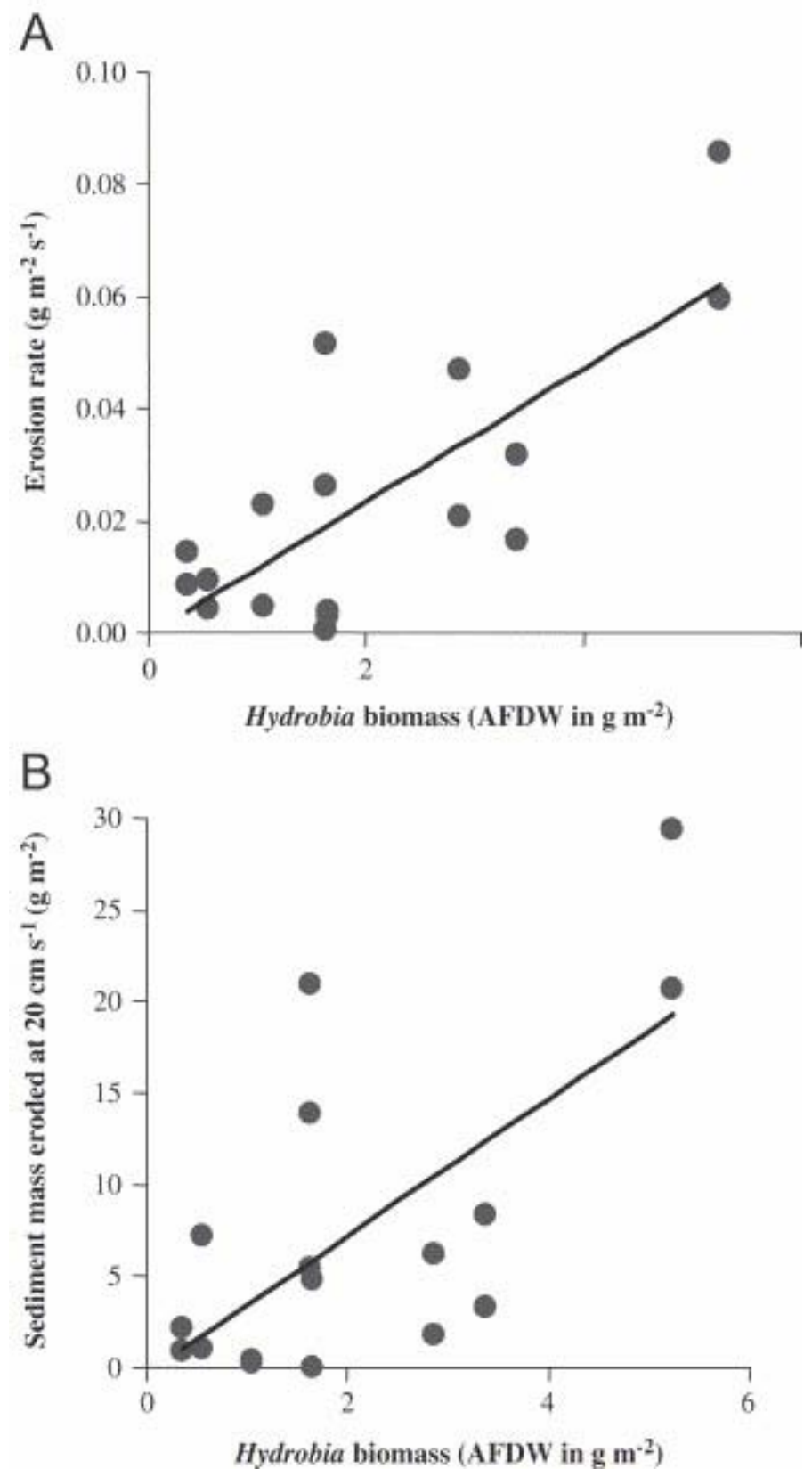

Fig. 8. Regression showing the relationships between the net erosion rate and Hydrobia ulvae biomass (A); and between the mass of the eroded sediment at $20 \mathrm{~cm} \mathrm{~s}^{-1}$ (i.e. the 8th step during erosion experiments) and Hydrobia ulvae biomass (B). 
A

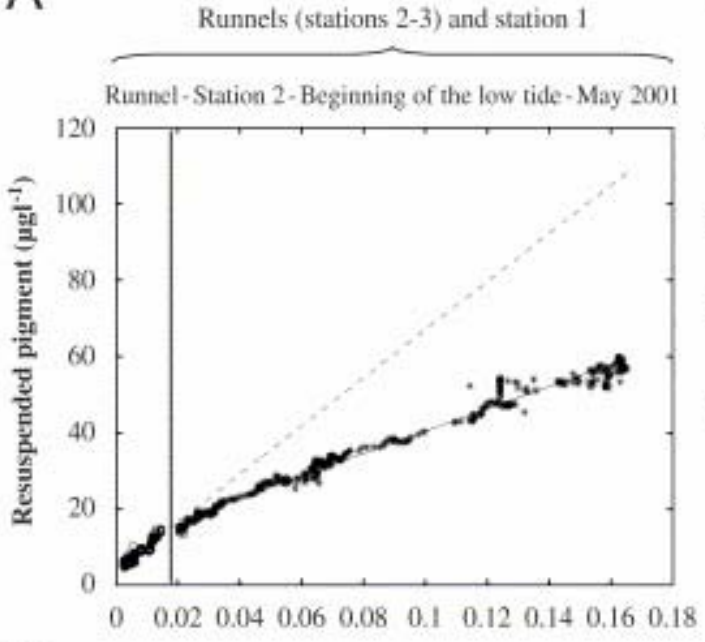

C

Runnel-Station 2-Beginning of the low tide- November 2000

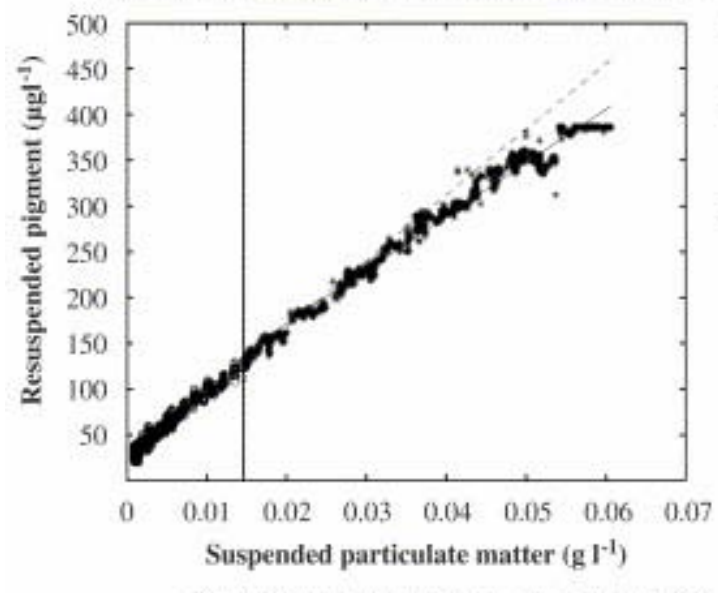

- Fluff layer erosion (regression : dashed line)
B

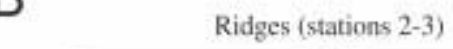

Ridge-Station 2-Beginning of the low tide-May 2001

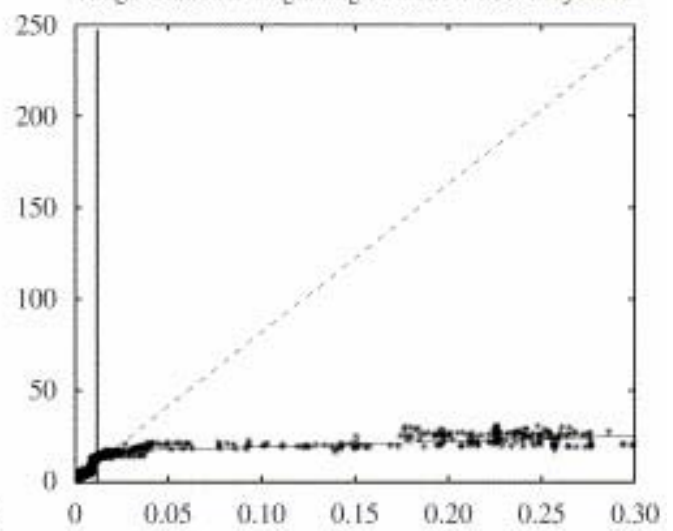

$D_{\text {Ridge-Station 2-Begimaing of the low tide-November } 2000}$

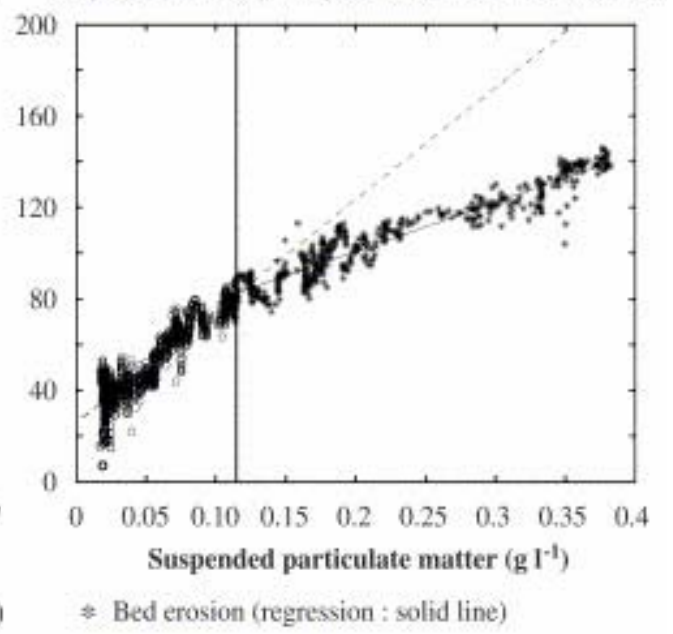

Fig. 9. Relationship between resuspended chl $a$ and SPM during four experiments $(A, B, C$, and D). Data during fluff layer erosion (between $\tau_{\text {fluff }}$ and $T_{\mathrm{cr}}$ ) are represented by circles (with regression lines as dashed lines), and data during bed erosion (after $T_{\mathrm{cr}}$ ) are represented by crosses (with regression lines as solid lines). The vertical line allows separation of data during fluff layer erosion from data during bed erosion. Two typical illustrations of soft sediments $(A, C)$, and two typical illustrations of consolidated sediments $(B, D)$ are shown. Regression coefficients are in Table 1. 


\section{Fluff layer erosion}

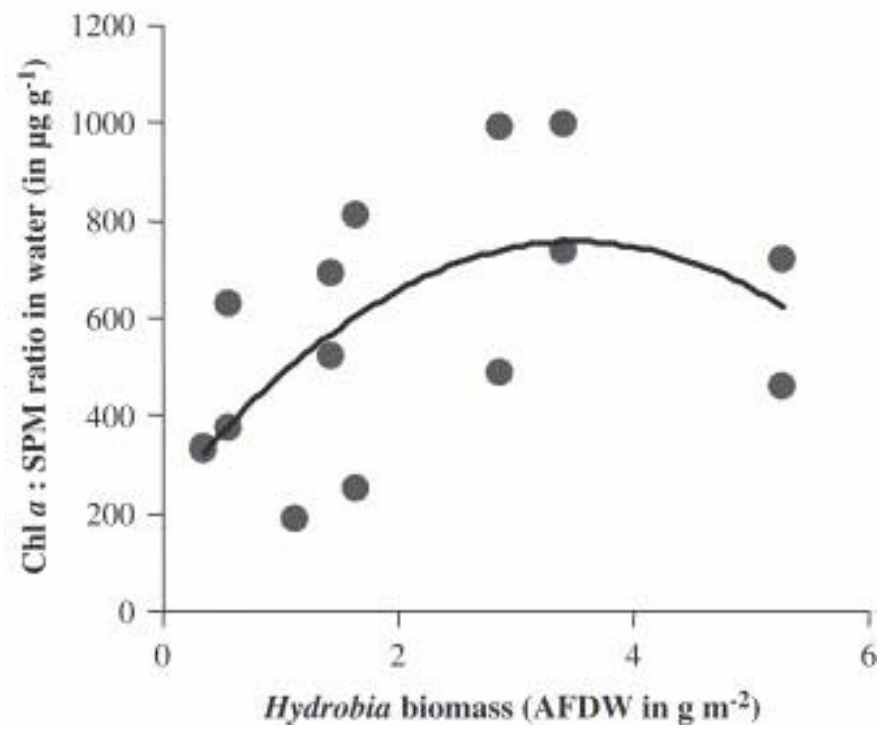

Fig. 10. Scatterplots of chl a: SPM ratios (during fluff layer erosion) as a function of the AFDW biomass of the gastropod Hydrobia ulvae. A non-linear regression line was estimated: $\mathrm{Chl} a$ : $\mathrm{SPM}=-43.4 x^{2}+302 x+221\left(r^{2}=0.36 ; F_{1,13}=7.45 ; p=0.017\right)$. 

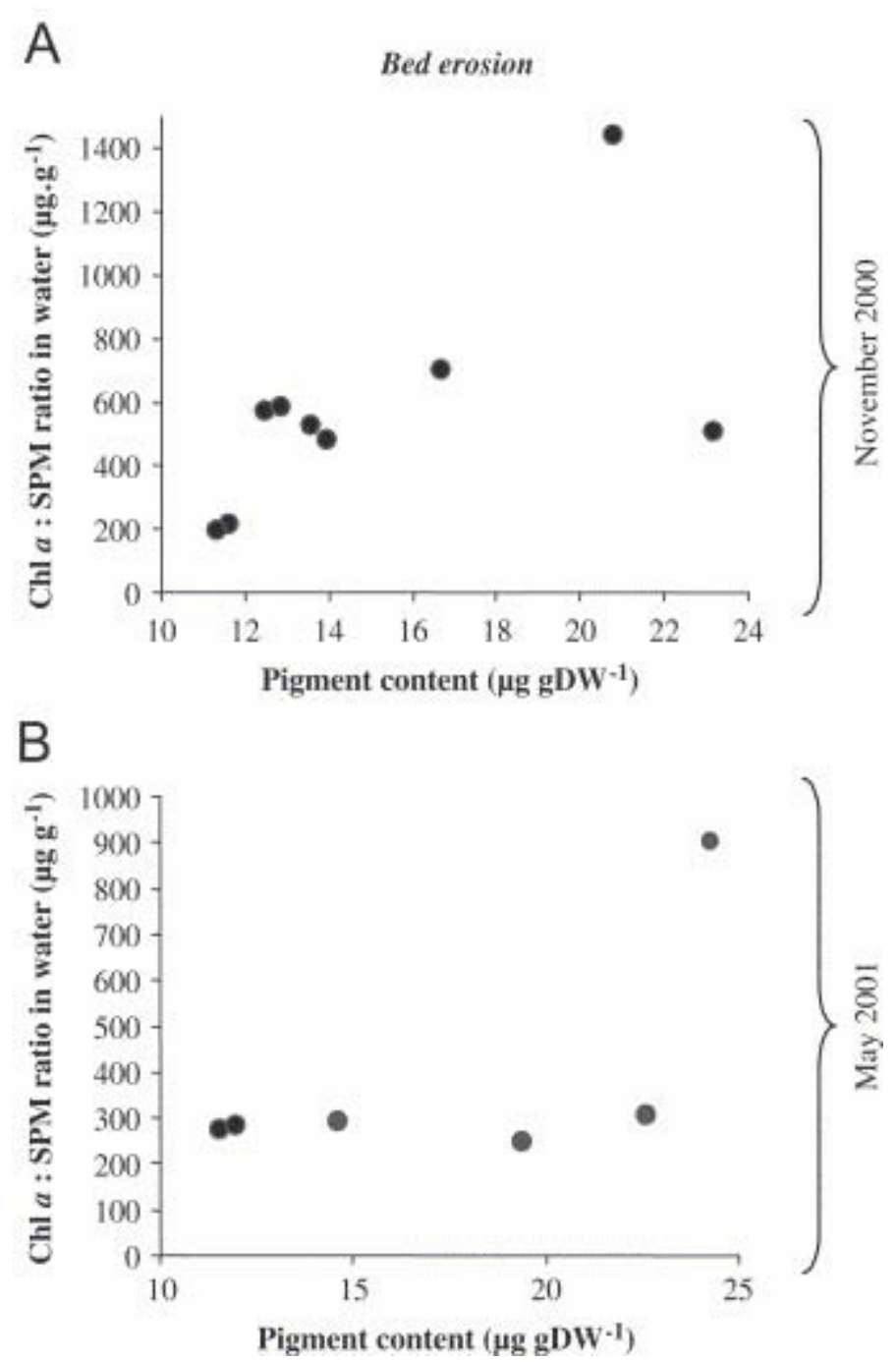

Fig. 11. Scatterplot of chl a: SPM (during bed erosion) as a function of sediment pigment content within the uppermost cm in November 2000 (A) and May 2001 (B). 


\section{Tables}

Table 1.

Summary of erosion experiment data and mean $( \pm S E)(n=5)$ sediment data. $K_{\mathrm{s}}$ is the Nikuradse coefficient, i.e. the index of bed roughness

\begin{tabular}{|c|c|c|c|c|c|c|c|c|c|c|c|c|c|}
\hline \multirow[t]{2}{*}{$\begin{array}{l}\text { Sampling } \\
\text { date }\end{array}$} & \multirow[t]{2}{*}{$\begin{array}{l}\text { Sampling } \\
\text { time* }\end{array}$} & \multirow[t]{2}{*}{ Station } & \multirow[t]{2}{*}{ Structure } & \multirow[t]{2}{*}{$\begin{array}{l}K_{\mathrm{s}} \\
(\mathrm{mm})\end{array}$} & \multirow{2}{*}{$\begin{array}{l}\text { Critical } \\
\text { threshold } \\
\text { (bed } \\
\text { erosion) } \\
\mathrm{Pa}\end{array}$} & \multicolumn{2}{|c|}{$\begin{array}{ll}\text { Erosion rate } & \text { rate } \\
\times 10^{-1}\left(\mathrm{~g} \mathrm{~m}^{-2} \mathrm{~s}^{-1}\right)\end{array}$} & \multicolumn{2}{|c|}{$\begin{array}{l}\text { Chl a : SPM ratio in } \\
\text { water }\left(\mu \mathrm{g} \mathrm{g}^{-1}\right)\end{array}$} & \multirow{2}{*}{$\begin{array}{l}\text { Dry } \\
\text { density } \\
\left(\mathrm{kg} \mathrm{m}^{-3}\right)\end{array}$} & \multirow{2}{*}{$\begin{array}{l}\text { Chl a } \\
\text { content } \\
\left(\mu \mathrm{gDW}{ }^{-1}\right)\end{array}$} & \multirow{2}{*}{$\begin{array}{l}\text { EPS } \\
\text { content } \\
\times 10^{-2} \\
\left(\mathrm{mg} \mathrm{gDW}^{-1}\right)\end{array}$} & \multirow{2}{*}{$\begin{array}{l}\text { LMW- } \\
\text { carbohydrate } \\
\text { content } \\
\times 10^{-2} \\
\left(\mathrm{mg} \mathrm{gDW}^{-1}\right)\end{array}$} \\
\hline & & & & & & $\begin{array}{l}\text { Fluff } \\
\text { layer } \\
\text { erosion }\end{array}$ & $\begin{array}{l}\text { Bed } \\
\text { erosion }\end{array}$ & $\begin{array}{l}\text { Fluff } \\
\text { layer } \\
\text { erosion }\end{array}$ & $\begin{array}{l}\text { Bed } \\
\text { erosion }\end{array}$ & & & & \\
\hline \multicolumn{14}{|l|}{$\begin{array}{l}\text { Winter } \\
2000\end{array}$} \\
\hline $\begin{array}{l}30 \text { Nov. } \\
2000\end{array}$ & 10:00 (B) & 1 & - & 1.9 & 0.10 & $<0.01$ & 0.59 & - & $\begin{array}{l}572 \\
\left(r^{2}=0.97\right)\end{array}$ & $719 \pm 147$ & $6.18 \pm 1.21$ & $11.06 \pm 1.86$ & $6.05 \pm 0.89$ \\
\hline $\begin{array}{l}30 \text { Nov. } \\
2000\end{array}$ & $\begin{array}{l}12: 15 \\
(\mathrm{M})\end{array}$ & 1 & - & 2.1 & 0.23 & 0.26 & 2.61 & $\begin{array}{l}692 \\
\left(r^{2}=0.58\right)\end{array}$ & $\begin{array}{l}461 \\
\left(r^{2}=0.97\right)\end{array}$ & - & - & - & - \\
\hline $\begin{array}{l}30 \text { Nov. } \\
2000\end{array}$ & $16: 00(E)$ & 1 & - & 12.4 & 0.37 & 0.51 & 1.12 & $\begin{array}{l}521 \\
\left(r^{2}=0.97\right)\end{array}$ & $\begin{array}{l}478 \\
\left(r^{2}=0.99\right)\end{array}$ & $662 \pm 66$ & $6.10 \pm 0.67$ & $12.38 \pm 1.49$ & $5.87 \pm 0.41$ \\
\hline $\begin{array}{l}29 \text { Nov. } \\
2000\end{array}$ & $11: 00$ (B) & 2 & Ridge & 0 & 2.41 & 0.47 & 3.24 & $\begin{array}{l}489 \\
\left(r^{2}=0.92\right)\end{array}$ & $\begin{array}{l}215 \\
\left(r^{2}=0.96\right)\end{array}$ & $575 \pm 57$ & $6.87 \pm 2.16$ & $8.40 \pm 1.58$ & $7.15 \pm 1.32$ \\
\hline $\begin{array}{l}29 \text { Nov. } \\
2000\end{array}$ & 13:35 (E) & 2 & Ridge & 0 & 0.36 & 0.21 & 1.50 & $\begin{array}{l}991 \\
\left(r^{2}=0.61\right)\end{array}$ & $\begin{array}{l}523 \\
\left(r^{2}=0.99\right)\end{array}$ & $551 \pm 13$ & $8.54 \pm 2.41$ & $8.69 \pm 1.06$ & $7.01 \pm 1.44$ \\
\hline $\begin{array}{l}01 \mathrm{Dec} . \\
2000\end{array}$ & $12: 45$ (B) & 2 & Runnel & 0 & 0.67 & 0.86 & 2.20 & $\begin{array}{l}717 \\
\left(r^{2}=0.99\right)\end{array}$ & $\begin{array}{l}585 \\
\left(r^{2}=0.99\right)\end{array}$ & $513 \pm 86$ & $5.58 \pm 1.81$ & $16.38 \pm 1.70$ & $12.37 \pm 3.58$ \\
\hline 01 Dec. & 15:00 (E) & 2 & Runnel & 2.0 & 0.30 & 0.60 & 1.54 & 458 & 507 & $411 \pm 112$ & $12.50 \pm 4.91$ & $12.05 \pm 0.78$ & $12.27 \pm 3.11$ \\
\hline
\end{tabular}




\begin{tabular}{|c|c|c|c|c|c|c|c|c|c|c|c|c|c|}
\hline \multirow[t]{2}{*}{$\begin{array}{l}\text { Sampling } \\
\text { date }\end{array}$} & \multirow[t]{2}{*}{$\begin{array}{l}\text { Sampling } \\
\text { time }\end{array}$} & \multirow[t]{2}{*}{ Station } & \multirow[t]{2}{*}{ Structure } & \multirow[t]{2}{*}{$\begin{array}{l}K_{\mathrm{s}} \\
(\mathrm{mm})\end{array}$} & \multirow{2}{*}{$\begin{array}{l}\text { Critical } \\
\text { threshold } \\
\text { (bed } \\
\text { erosion) } \\
\mathrm{Pa}\end{array}$} & \multicolumn{2}{|c|}{$\begin{array}{l}\text { Erosion rate } \\
\times 10^{-1}\left(\mathrm{~g} \mathrm{~m}^{-2} \mathrm{~s}^{-1}\right)\end{array}$} & \multicolumn{2}{|c|}{$\begin{array}{l}\text { Chl a : SPM ratio in } \\
\text { water }\left(\mu \mathrm{g} \mathrm{g}^{-1}\right)\end{array}$} & \multirow{2}{*}{$\begin{array}{l}\text { Dry } \\
\text { density } \\
\left(\mathrm{kg} \mathrm{m}^{-3}\right)\end{array}$} & \multirow{2}{*}{$\begin{array}{l}\text { Chl a } \\
\text { content } \\
\left(\mu \mathrm{gDW}{ }^{-1}\right)\end{array}$} & \multirow{2}{*}{$\begin{array}{l}\text { EPS } \\
\text { content } \\
\times 10^{-2} \\
\left(\mathrm{mg} \mathrm{gDW}^{-1}\right)\end{array}$} & \multirow{2}{*}{$\begin{array}{l}\text { LMW- } \\
\text { carbohydrate } \\
\text { content } \\
\times 10^{-2} \\
\left(\mathrm{mg} \mathrm{gDW}^{-1}\right)\end{array}$} \\
\hline & & & & & & $\begin{array}{l}\text { Fluff } \\
\text { layer } \\
\text { erosion }\end{array}$ & $\begin{array}{l}\text { Bed } \\
\text { erosion }\end{array}$ & $\begin{array}{l}\text { Fluff } \\
\text { layer } \\
\text { erosion }\end{array}$ & $\begin{array}{l}\text { Bed } \\
\text { erosion }\end{array}$ & & & & \\
\hline 2000 & & & & & & & & $\left(r^{2}=0.72\right)$ & $\left(r^{2}=0.99\right)$ & & & & \\
\hline $\begin{array}{l}27 \text { Nov. } \\
2000\end{array}$ & 09:30 (B) & 3 & Ridge & 0 & 1.08 & 0.05 & 0.42 & - & - & $652 \pm 65$ & $8.69 \pm 3.42$ & $7.74 \pm 0.87$ & $4.11 \pm 1.21$ \\
\hline $\begin{array}{l}27 \text { Nov. } \\
2000\end{array}$ & $11: 30(E)$ & 3 & Ridge & 0.5 & 2.64 & 0.23 & 2.56 & $\begin{array}{l}185 \\
\left(r^{2}=0.47\right)\end{array}$ & $\begin{array}{l}198 \\
\left(r^{2}=0.89\right)\end{array}$ & $743 \pm 35$ & $5.87 \pm 2.52$ & $10.00 \pm 1.53$ & $4.35 \pm 0.51$ \\
\hline $\begin{array}{l}28 \text { Nov. } \\
2000\end{array}$ & $10: 45$ (B) & 3 & Runnel & 0 & 0.57 & 0.08 & 1.76 & $\begin{array}{l}995 \\
\left(r^{2}=0.57\right)\end{array}$ & $\begin{array}{l}1438 \\
\left(r^{2}=0.99\right)\end{array}$ & $528 \pm 80$ & $9.44 \pm 2.90$ & $7.32 \pm 1.89$ & $7.29 \pm 2.49$ \\
\hline $\begin{array}{l}28 \text { Nov. } \\
2000\end{array}$ & $13: 45(E)$ & 3 & Runnel & 5.5 & 0.61 & 0.32 & 1.49 & $\begin{array}{l}734 \\
\left(r^{2}=0.80\right)\end{array}$ & $\begin{array}{l}700 \\
\left(r^{2}=0.97\right)\end{array}$ & $428 \pm 77$ & $9.26 \pm 2.23$ & $8.12 \pm 1.26$ & $6.07 \pm 0.77$ \\
\hline \multicolumn{14}{|l|}{$\begin{array}{l}\text { Spring } \\
2001\end{array}$} \\
\hline $\begin{array}{l}02 \text { May } \\
2001\end{array}$ & $06: 45$ (B) & 1 & - & - & 0.73 & 0.08 & 0.34 & $\begin{array}{l}273 \\
\left(r^{2}=0.93\right)\end{array}$ & $\begin{array}{l}337 \\
\left(r^{2}=0.98\right)\end{array}$ & $701 \pm 96$ & $6.08 \pm 1.04$ & $8.60 \pm 2.38$ & $6.59 \pm 0.91$ \\
\hline $\begin{array}{l}02 \text { May } \\
2001\end{array}$ & 10:15 (E) & 1 & - & - & 0.68 & 0.14 & 0.46 & $\begin{array}{l}284 \\
\left(r^{2}=0.94\right)\end{array}$ & $\begin{array}{l}328 \\
\left(r^{2}=0.98\right)\end{array}$ & $747 \pm 117$ & $6.41 \pm 0.32$ & $8.66 \pm 3.44$ & $6.81 \pm 2.38$ \\
\hline $\begin{array}{l}03 \text { May } \\
2001\end{array}$ & $06: 20(B)$ & 2 & Ridge & - & 2.37 & 0.04 & 1.49 & $\begin{array}{l}304 \\
\left(r^{2}=0.90\right)\end{array}$ & $\begin{array}{l}809 \\
\left(r^{2}=0.77\right)\end{array}$ & $661 \pm 88$ & $13.60 \pm 2.21$ & $12.38 \pm 1.05$ & $15.54 \pm 1.14$ \\
\hline 03 May & 09:15 (E) & 2 & Ridge & - & 2.64 & 0.03 & 1.67 & 899 & 246 & $689 \pm 35$ & $15.51 \pm 2.09$ & $10.96 \pm 1.55$ & $22.33 \pm 2.95$ \\
\hline
\end{tabular}




\begin{tabular}{|c|c|c|c|c|c|c|c|c|c|c|c|c|c|}
\hline \multirow[t]{2}{*}{$\begin{array}{l}\text { Sampling } \\
\text { date }\end{array}$} & \multirow[t]{2}{*}{$\begin{array}{l}\text { Sampling } \\
\text { time* }\end{array}$} & \multirow[t]{2}{*}{ Station } & \multirow[t]{2}{*}{ Structure } & \multirow[t]{2}{*}{$\begin{array}{l}K_{\mathrm{s}} \\
(\mathrm{mm})\end{array}$} & \multirow{2}{*}{$\begin{array}{l}\text { Critical } \\
\text { threshold } \\
\text { (bed } \\
\text { erosion) } \\
\mathrm{Pa}\end{array}$} & \multicolumn{2}{|c|}{$\begin{array}{l}\text { Erosion rate } \\
\times 10^{-1}\left(\mathrm{~g} \mathrm{~m}^{-2} \mathrm{~s}^{-1}\right)\end{array}$} & \multicolumn{2}{|c|}{$\begin{array}{l}\text { Chl a : SPM ratio in } \\
\text { water }\left(\mu \mathrm{g} \mathrm{g}^{-1}\right)\end{array}$} & \multirow{2}{*}{$\begin{array}{l}\text { Dry } \\
\text { density } \\
\left(\mathrm{kg} \mathrm{m}^{-3}\right)\end{array}$} & \multirow{2}{*}{$\begin{array}{l}\text { Chl a } \\
\text { content } \\
\left(\mu g \mathrm{gDW}^{-1}\right)\end{array}$} & \multirow{2}{*}{$\begin{array}{l}\text { EPS } \\
\text { content } \\
\times 10^{-2} \\
\left(\mathrm{mg} \mathrm{gDW}^{-1}\right)\end{array}$} & \multirow{2}{*}{$\begin{array}{l}\text { LMW- } \\
\text { carbohydrate } \\
\text { content } \\
\times 10^{-2} \\
\left(\mathrm{mg} \mathrm{gDW}^{-1}\right)\end{array}$} \\
\hline & & & & & & $\begin{array}{l}\text { Fluff } \\
\text { layer } \\
\text { erosion }\end{array}$ & $\begin{array}{l}\text { Bed } \\
\text { erosion }\end{array}$ & $\begin{array}{l}\text { Fluff } \\
\text { layer } \\
\text { erosion }\end{array}$ & $\begin{array}{l}\text { Bed } \\
\text { erosion }\end{array}$ & & & & \\
\hline 2001 & & & & & & & & $\left(r^{2}=0.62\right)$ & $\left(r^{2}=0.88\right)$ & & & & \\
\hline $\begin{array}{l}04 \text { May } \\
2001\end{array}$ & 07:00 (B) & 2 & Runnel & 6.9 & 0.66 & 0.09 & 1.26 & $\begin{array}{l}292 \\
\left(r^{2}=0.96\right)\end{array}$ & $\begin{array}{l}631 \\
\left(r^{2}=0.99\right)\end{array}$ & $509 \pm 31$ & $9.52 \pm 1.24$ & $12.22 \pm 0.86$ & $12.69 \pm 2.03$ \\
\hline $\begin{array}{l}04 \text { May } \\
2001\end{array}$ & $11: 10(\mathrm{E})$ & 2 & Runnel & 5.6 & 0.64 & 0.04 & 0.76 & $\begin{array}{l}245 \\
\left(r^{2}=0.47\right)\end{array}$ & $\begin{array}{l}372 \\
\left(r^{2}=0.99\right)\end{array}$ & $613 \pm 49$ & $10.09 \pm 2.25$ & $14.67 \pm 2.97$ & $20.42 \pm 3.51$ \\
\hline $\begin{array}{l}05 \text { May } \\
2001\end{array}$ & $08: 30$ (B) & 3 & Ridge & - & - & - & - & - & - & $675 \pm 51$ & $9.24 \pm 1.84$ & $14.54 \pm 1.86$ & $6.73 \pm 1.12$ \\
\hline $\begin{array}{l}05 \text { May } \\
2001\end{array}$ & $12: 15(E)$ & 3 & Ridge & - & - & - & - & - & - & $769 \pm 51$ & $8.04 \pm 1.91$ & $16.08 \pm 4.46$ & $8.71 \pm 2.37$ \\
\hline $\begin{array}{l}05 \text { May } \\
2001\end{array}$ & $08: 30$ (B) & 3 & Runnel & - & - & - & - & - & - & $624 \pm 48$ & $9.20 \pm 1.60$ & $17.01 \pm 2.74$ & $9.93 \pm 1.88$ \\
\hline $\begin{array}{l}05 \text { May } \\
2001\end{array}$ & $11: 45(E)$ & 3 & Runnel & - & - & - & - & - & - & $702 \pm 30$ & $7.36 \pm 1.50$ & $19.05 \pm 2.67$ & $8.19 \pm 1.69$ \\
\hline
\end{tabular}

*indicates the sampling time during the emersion period: $B=B$ Beginning; $M=M i d d l e ; E=E n d$ 
Table 2.

Macrofauna from cores $(n=5)$ collected during winter (November 2000). Densities are expressed as ind. $\mathrm{m}^{-2}$, and biomasses as $\mathrm{g} \mathrm{AFDW} \mathrm{m}^{-2}$

\begin{tabular}{|c|c|c|c|c|c|c|c|c|c|c|c|}
\hline \multirow{2}{*}{$\begin{array}{l}\text { Taxonomic } \\
\text { group }\end{array}$} & \multirow{2}{*}{ Species } & \multicolumn{5}{|c|}{ Density ( \pm SE) } & \multicolumn{5}{|c|}{ Biomass ( \pm SE) } \\
\hline & & Station 1 & $\begin{array}{l}\text { Station } 2 \\
\text { Ridge }\end{array}$ & $\begin{array}{l}\text { Station } 2 \\
\text { Runnel }\end{array}$ & $\begin{array}{l}\text { Station } 3 \\
\text { Ridge }\end{array}$ & $\begin{array}{l}\text { Station } 3 \\
\text { Runnel }\end{array}$ & Station 1 & $\begin{array}{l}\text { Station } 2 \\
\text { Ridge }\end{array}$ & $\begin{array}{l}\text { Station } 2 \\
\text { Runnel }\end{array}$ & $\begin{array}{l}\text { Station } 3 \\
\text { Ridge }\end{array}$ & $\begin{array}{l}\text { Station } \\
\text { Runnel }\end{array}$ \\
\hline \multirow[t]{5}{*}{ Gastropoda } & Hydrobia ulvae & $2422 \pm 957$ & $3520 \pm 619$ & $4878 \pm 821$ & $340 \pm 330$ & $3475 \pm 357$ & $1.42 \pm 0.57$ & $2.87 \pm 0.57$ & $5.25 \pm 1.67$ & $0.45 \pm 0.44$ & $3.39 \pm 0.40$ \\
\hline & Haminoea sp. & 0 & 0 & 0 & 0 & $11 \pm 11$ & 0 & 0 & 0 & 0 & $0.01 \pm 0.01$ \\
\hline & Littorina littorea & 0 & 0 & $23 \pm 23$ & 0 & 0 & 0 & 0 & $0.01 \pm 0.01$ & 0 & 0 \\
\hline & $\begin{array}{l}\text { Retusa } \\
\text { truncatula }\end{array}$ & $23 \pm 14$ & 0 & 0 & 0 & $11 \pm 11$ & $0.01 \pm 0.01$ & 0 & 0 & 0 & $0.01 \pm 0.01$ \\
\hline & $\begin{array}{l}\text { Turbonilla } \\
\text { lactea }\end{array}$ & $23 \pm 23$ & 0 & $23 \pm 23$ & 0 & $34 \pm 23$ & $0.01 \pm 0.01$ & 0 & $0.01 \pm 0.01$ & 0 & $0.02 \pm 0.01$ \\
\hline \multirow[t]{7}{*}{ Bivalvia } & Abra nitida & $11 \pm 11$ & 0 & 0 & 0 & $57 \pm 57$ & $0.01 \pm 0.01$ & 0 & 0 & 0 & $0.04 \pm 0.04$ \\
\hline & Abra tenuis & $283 \pm 78$ & $34 \pm 34$ & $91 \pm 46$ & $34 \pm 54$ & $23 \pm 23$ & $0.13 \pm 0.03$ & $0.03 \pm 0.03$ & $0.06 \pm 0.04$ & $0.04 \pm 0.06$ & $0.03 \pm 0.03$ \\
\hline & $\begin{array}{l}\text { Cerastoderma } \\
\text { edule }\end{array}$ & $57 \pm 44$ & $34 \pm 23$ & $11 \pm 11$ & $57 \pm 89$ & $57 \pm 25$ & $0.03 \pm 0.02$ & $0.02 \pm 0.01$ & $0.01 \pm 0.01$ & $0.30 \pm 0.47$ & $0.48 \pm 0.37$ \\
\hline & Corbula gibba & 0 & 0 & $11 \pm 11$ & 0 & 0 & 0 & 0 & $0.01 \pm 0.01$ & 0 & 0 \\
\hline & $\begin{array}{l}\text { Macoma } \\
\text { balthica }\end{array}$ & $136 \pm 29$ & $23 \pm 14$ & $136 \pm 52$ & $11 \pm 18$ & $68 \pm 42$ & $0.96 \pm 0.12$ & $0.31 \pm 0.19$ & $0.14 \pm 0.14$ & $0.01 \pm 0.02$ & 0.07士à;à' \\
\hline & $\begin{array}{l}\text { Scrobicularia } \\
\text { plana }\end{array}$ & $1064 \pm 60$ & $57 \pm 57$ & 0 & 0 & 0 & $32.47 \pm 8.04$ & $0.02 \pm 0.02$ & 0 & 0 & 0 \\
\hline & Spisula & 0 & 0 & 0 & 0 & $11 \pm 11$ & 0 & 0 & 0 & 0 & $0.11 \pm 0.11$ \\
\hline
\end{tabular}




\begin{tabular}{|c|c|c|c|c|c|c|c|c|c|c|c|}
\hline \multirow{2}{*}{$\begin{array}{l}\text { Taxonomic } \\
\text { group }\end{array}$} & \multirow{2}{*}{ Species } & \multicolumn{5}{|c|}{ Density ( \pm SE) } & \multicolumn{5}{|c|}{ Biomass $( \pm \mathrm{SE})$} \\
\hline & & Station 1 & $\begin{array}{l}\text { Station } 2 \\
\text { Ridge }\end{array}$ & $\begin{array}{l}\text { Station } 2 \\
\text { Runnel }\end{array}$ & $\begin{array}{l}\text { Station } 3 \\
\text { Ridge }\end{array}$ & $\begin{array}{l}\text { Station } 3 \\
\text { Runnel }\end{array}$ & Station 1 & $\begin{array}{l}\text { Station } 2 \\
\text { Ridge }\end{array}$ & $\begin{array}{l}\text { Station } 2 \\
\text { Runnel }\end{array}$ & $\begin{array}{l}\text { Station } 3 \\
\text { Ridge }\end{array}$ & $\begin{array}{l}\text { Station } \\
\text { Runnel }\end{array}$ \\
\hline & subtrunta & & & & & & & & & & \\
\hline \multirow[t]{10}{*}{ Polychaeta } & $\begin{array}{l}\text { Aphelochaeta } \\
\text { (= Tharyx) } \\
\text { marioni }\end{array}$ & $283 \pm 80$ & $158 \pm 66$ & $487 \pm 240$ & $158 \pm 153$ & $1901 \pm 591$ & $0.06 \pm 0.02$ & $0.02 \pm 0.01$ & $0.10 \pm 0.05$ & $0.03 \pm 0.03$ & $0.38 \pm 0.12$ \\
\hline & Capitellidae sp. & $192 \pm 118$ & 0 & 0 & 0 & 0 & $0.02 \pm 0.01$ & 0 & 0 & 0 & 0. \\
\hline & $\begin{array}{l}\text { Chaetezone } \\
\text { caputesocis }\end{array}$ & 0 & 0 & 0 & 0 & $11 \pm 11$ & 0 & 0 & 0 & 0 & $0.01 \pm 0.01$ \\
\hline & Clymenura sp. & 0 & 0 & 0 & 0 & $57 \pm 57$ & 0 & 0 & 0 & 0 & $0.01 \pm 0.01$ \\
\hline & $\begin{array}{l}\text { Cossura } \\
\text { pygodactylata }\end{array}$ & 0 & 0 & 0 & 0 & $79 \pm 52$ & 0 & 0 & 0 & 0 & $0.01 \pm 0.01$ \\
\hline & $\begin{array}{l}\text { Hediste } \\
\text { diversicolor }\end{array}$ & $475 \pm 248$ & $543 \pm 170$ & $68 \pm 42$ & $249 \pm 266$ & $170 \pm 74$ & $1.82 \pm 0.75$ & $1.63 \pm 0.51$ & $0.20 \pm 0.12$ & $0.07 \pm 0.08$ & $0.59 \pm 0.26$ \\
\hline & $\begin{array}{l}\text { Heteromastus } \\
\text { filiformis }\end{array}$ & $34 \pm 23$ & 0 & 0 & 0 & 0 & $0.02 \pm 0.01$ & 0 & 0 & 0 & 0 \\
\hline & Maldanidae sp. & 0 & 0 & 0 & $113 \pm 179$ & $45 \pm 45$ & 0 & 0 & 0 & $0.01 \pm 0.01$ & $0.01 \pm 0.01$ \\
\hline & $\begin{array}{l}\text { Myriochele } \\
\text { oculata }\end{array}$ & $509 \pm 322$ & $45 \pm 11$ & 0 & $23 \pm 22$ & 0 & $0.05 \pm 0.03$ & $0.01 \pm 0.01$ & 0 & $0.01 \pm 0.01$ & 0 \\
\hline & $\begin{array}{l}\text { Neanthes } \\
\text { succinea }\end{array}$ & $34 \pm 23$ & 0 & 0 & 0 & 0 & $0.17 \pm 0.11$ & 0 & 0 & 0 & 0 \\
\hline
\end{tabular}




\begin{tabular}{|c|c|c|c|c|c|c|c|c|c|c|c|}
\hline \multirow{2}{*}{$\begin{array}{l}\text { Taxonomic } \\
\text { group }\end{array}$} & \multirow{2}{*}{ Species } & \multicolumn{5}{|c|}{ Density ( \pm SE) } & \multicolumn{5}{|c|}{ Biomass ( \pm SE) } \\
\hline & & Station 1 & $\begin{array}{l}\text { Station } 2 \\
\text { Ridge }\end{array}$ & $\begin{array}{l}\text { Station } 2 \\
\text { Runnel }\end{array}$ & $\begin{array}{l}\text { Station } 3 \\
\text { Ridge }\end{array}$ & $\begin{array}{l}\text { Station } 3 \\
\text { Runnel }\end{array}$ & Station 1 & $\begin{array}{l}\text { Station } 2 \\
\text { Ridge }\end{array}$ & $\begin{array}{l}\text { Station } 2 \\
\text { Runnel }\end{array}$ & $\begin{array}{l}\text { Station } 3 \\
\text { Ridge }\end{array}$ & $\begin{array}{l}\text { Station } \\
\text { Runnel }\end{array}$ \\
\hline & $\begin{array}{l}\text { Nephtys } \\
\text { hombergii }\end{array}$ & $34 \pm 14$ & $147 \pm 38$ & $45 \pm 21$ & $57 \pm 57$ & $147 \pm 29$ & $0.31 \pm 0.19$ & $1.29 \pm 0.28$ & $0.18 \pm 0.10$ & $0.24 \pm 0.37$ & $0.30 \pm 0.16$ \\
\hline & $\begin{array}{l}\text { Nephtys } \\
\text { hystricis }\end{array}$ & 0 & $34 \pm 23$ & $45 \pm 21$ & 0 & $91 \pm 29$ & 0 & $0.10 \pm 0.07$ & $0.21 \pm 0.11$ & 0 & $0.18 \pm 0.06$ \\
\hline & $\begin{array}{l}\text { Polydora } \\
\text { cornuta }\end{array}$ & $102 \pm 68$ & 0 & $11 \pm 11$ & $11 \pm 18$ & 0 & $0.03 \pm 0.02$ & 0 & $0.01 \pm 0.01$ & $0.01 \pm 0.01$ & 0 \\
\hline & $\begin{array}{l}\text { Pseudopolydora } \\
\text { antennata }\end{array}$ & $634 \pm 338$ & $215 \pm 63$ & $124 \pm 38$ & $11 \pm 18$ & $487 \pm 113$ & $0.19 \pm 0.10$ & $0.06 \pm 0.02$ & $0.04 \pm 0.01$ & $0.01 \pm 0.01$ & $0.15 \pm 0.03$ \\
\hline & $\begin{array}{l}\text { Pygospio } \\
\text { elegans }\end{array}$ & $57 \pm 57$ & 0 & 0 & $11 \pm 18$ & 0 & $0.01 \pm 0.01$ & 0 & 0 & $0.01 \pm 0.01$ & 0 \\
\hline & Spio decorratus & $11 \pm 11$ & 0 & 0 & $11 \pm 18$ & 0 & $0.01 \pm 0.01$ & 0 & 0 & $0.01 \pm 0.01$ & 0 \\
\hline & Spionidae sp. & 0 & 0 & 0 & 0 & $45 \pm 33$ & 0 & 0 & 0 & 0 & $0.01 \pm 0.01$ \\
\hline & $\begin{array}{l}\text { Streblospio } \\
\text { shrubsolii }\end{array}$ & $815 \pm 298$ & $2422 \pm 532$ & $1166 \pm 503$ & $1064 \pm 1068$ & $3418 \pm 999$ & $0.16 \pm 0.06$ & $0.48 \pm 0.11$ & $0.23 \pm 0.10$ & $0.21 \pm 0.21$ & $0.68 \pm 0.20$ \\
\hline \multirow[t]{2}{*}{ Oligochaeta } & $\begin{array}{l}\text { Tubificoides } \\
\text { benedeni }\end{array}$ & $192 \pm 66$ & $113 \pm 51$ & $23 \pm 23$ & 0 & $34 \pm 14$ & $0.02 \pm 0.01$ & $0.01 \pm 0.01$ & $0.01 \pm 0.01$ & 0 & $0.01 \pm 0.01$ \\
\hline & Oligochaeta spp & 0 & 0 & 0 & 0 & $11 \pm 11$ & 0 & 0 & 0 & 0 & 020 \\
\hline Nemertea & Nemertea spp & 0 & 0 & 0 & 0 & $23 \pm 14$ & 0 & 0 & 0 & 0 & $0.01 \pm 0.0120$ \\
\hline Amphipoda & Corophium & 0 & $34 \pm 14$ & 0 & 0 & 0 & 0 & $0.01 \pm 0.01$ & 0 & 0 & 020 \\
\hline
\end{tabular}




\begin{tabular}{|c|c|c|c|c|c|c|c|c|c|c|c|}
\hline \multirow{2}{*}{$\begin{array}{l}\text { Taxonomic } \\
\text { group }\end{array}$} & \multirow{2}{*}{ Species } & \multicolumn{5}{|c|}{ Density $( \pm S E)$} & \multicolumn{5}{|c|}{ Biomass $( \pm S E)$} \\
\hline & & Station 1 & $\begin{array}{l}\text { Station } 2 \\
\text { Ridge }\end{array}$ & $\begin{array}{l}\text { Station } 2 \\
\text { Runnel }\end{array}$ & $\begin{array}{l}\text { Station } 3 \\
\text { Ridge }\end{array}$ & $\begin{array}{l}\text { Station } 3 \\
\text { Runnel }\end{array}$ & Station 1 & $\begin{array}{l}\text { Station } 2 \\
\text { Ridge }\end{array}$ & $\begin{array}{l}\text { Station } 2 \\
\text { Runnel }\end{array}$ & $\begin{array}{l}\text { Station } 3 \\
\text { Ridge }\end{array}$ & $\begin{array}{l}\text { Station } \\
\text { Runnel }\end{array}$ \\
\hline & volutator & & & & & & & & & & \\
\hline Decapoda & $\begin{array}{l}\text { Crangon } \\
\text { crangon }\end{array}$ & 0 & 0 & 0 & 0 & $34 \pm 23$ & 0 & 0 & 0 & 0 & $0.01 \pm 0.01$ \\
\hline
\end{tabular}

Values of density and biomass of the dominant species are shown in italics.

Table 3.

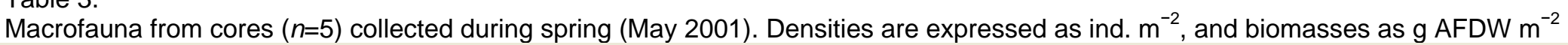

\begin{tabular}{|c|c|c|c|c|c|c|c|c|c|c|c|}
\hline \multirow{2}{*}{$\begin{array}{l}\text { Taxonomic } \\
\text { group }\end{array}$} & \multirow{2}{*}{ Species } & \multicolumn{5}{|c|}{ Density ( \pm SE) } & \multicolumn{5}{|c|}{ Biomass $( \pm S E)$} \\
\hline & & $\begin{array}{l}\text { Station } \\
1\end{array}$ & $\begin{array}{ll}\text { Station } & 2 \\
\text { Ridge } & \end{array}$ & $\begin{array}{l}\text { Station } \\
2 \\
\text { Runnel }\end{array}$ & $\begin{array}{l}\text { Station } 3 \\
\text { Ridge }\end{array}$ & $\begin{array}{l}\text { Station } \\
3 \\
\text { Runnel }\end{array}$ & Station 1 & $\begin{array}{l}\text { Station } 2 \\
\text { Ridge }\end{array}$ & $\begin{array}{l}\text { Station } 2 \\
\text { Runnel }\end{array}$ & $\begin{array}{l}\text { Station } 3 \\
\text { Ridge }\end{array}$ & $\begin{array}{l}\text { Station } \\
\text { Runnel }\end{array}$ \\
\hline \multirow[t]{3}{*}{ Gastropoda } & Hydrobia ulvae & $475 \pm 203$ & $1743 \pm 395$ & $724 \pm 325$ & $34 \pm 14$ & $543 \pm 208$ & $0.36 \pm 0.14$ & $1.65 \pm 0.53$ & $0.55 \pm 0.23$ & $0.08 \pm 0.04$ & $0.72 \pm 0.27$ \\
\hline & Littorina littorea & 0 & 0 & $11 \pm 11$ & 0 & 0 & 0 & 0 & $0.01 \pm 0.01$ & 0 & 0 \\
\hline & $\begin{array}{l}\text { Retusa } \\
\text { truncatula }\end{array}$ & 0 & $11 \pm 11$ & $34 \pm 34$ & 0 & $23 \pm 23$ & 0 & $0.01 \pm 0.01$ & $0.01 \pm 0.01$ & 0 & $0.01 \pm 0.0120$ \\
\hline \multirow[t]{4}{*}{ Bivalvia } & Abra nitida & 0 & 0 & $57 \pm 44$ & $11 \pm 11$ & $79 \pm 52$ & 0 & 0 & $0.01 \pm 0.01$ & $0.01 \pm 0.01$ & $0.04 \pm 0.03$ \\
\hline & Abra tenuis & $136 \pm 58$ & $102 \pm 63$ & $124 \pm 85$ & 0 & $11 \pm 11$ & $0.03 \pm 0.01$ & $0.01 \pm 0.01$ & $0.06 \pm 0.04$ & 0 & $0.02 \pm 0.02$ \\
\hline & $\begin{array}{l}\text { Macoma } \\
\text { balthica }\end{array}$ & $532 \pm 148$ & $113 \pm 59$ & $215 \pm 109$ & $11 \pm 11$ & $34 \pm 14$ & $1.63 \pm 0.60$ & $0.49 \pm 0.35$ & $0.64 \pm 0.45$ & $0.04 \pm 0.04$ & $0.14 \pm 0.10$ \\
\hline & Mysella & $23 \pm 14$ & 0 & 0 & 0 & 0 & $0.03 \pm 0.02$ & 0 & 0 & 0 & 0 \\
\hline
\end{tabular}




\begin{tabular}{|c|c|c|c|c|c|c|c|c|c|c|c|}
\hline \multirow{2}{*}{$\begin{array}{l}\text { Taxonomic } \\
\text { group }\end{array}$} & \multirow{2}{*}{ Species } & \multicolumn{5}{|c|}{ Density ( \pm SE) } & \multicolumn{5}{|c|}{ Biomass ( \pm SE) } \\
\hline & & $\begin{array}{l}\text { Station } \\
1\end{array}$ & $\begin{array}{l}\text { Station } 2 \\
\text { Ridge }\end{array}$ & $\begin{array}{l}\text { Station } \\
2 \\
\text { Runnel }\end{array}$ & $\begin{array}{l}\text { Station } 3 \\
\text { Ridge }\end{array}$ & $\begin{array}{l}\text { Station } \\
3 \\
\text { Runnel }\end{array}$ & Station 1 & $\begin{array}{l}\text { Station } 2 \\
\text { Ridge }\end{array}$ & $\begin{array}{l}\text { Station } 2 \\
\text { Runnel }\end{array}$ & $\begin{array}{l}\text { Station } 3 \\
\text { Ridge }\end{array}$ & $\begin{array}{l}\text { Station } \\
\text { Runnel }\end{array}$ \\
\hline & bidentata & & & & & & & & & & \\
\hline & $\begin{array}{l}\text { Scrobicularia } \\
\text { plana }\end{array}$ & $747 \pm 167$ & $102 \pm 42$ & $226 \pm 142$ & $91 \pm 52$ & $11 \pm 11$ & $18.00 \pm 3.41$ & $0.66 \pm 0.37$ & $1.77 \pm 0.68$ & $2.09 \pm 1.98$ & $0.01 \pm 0.0120$ \\
\hline \multirow[t]{10}{*}{ Polychaeta } & $\begin{array}{l}\text { Aphelochaeta } \\
\text { marioni }\end{array}$ & $249 \pm 81$ & $396 \pm 232$ & $407 \pm 283$ & $91 \pm 29$ & $792 \pm 408$ & $0.05 \pm 0.02$ & $0.09 \pm 0.05$ & $0.08 \pm 0.06$ & $0.14 \pm 0.06$ & $0.16 \pm 0.08$ \\
\hline & Capitellidae sp. & $181 \pm 167$ & $11 \pm 11$ & $113 \pm 113$ & $23 \pm 23$ & $11 \pm 11$ & $0.02 \pm 0.02$ & $0.01 \pm 0.01$ & $0.01 \pm 0.01$ & $0.01 \pm 0.01$ & $0.01 \pm 0.01$ \\
\hline & $\begin{array}{l}\text { Cossura } \\
\text { pygodactylata }\end{array}$ & 0 & 0 & $11 \pm 11$ & 0 & $11 \pm 11$ & 0 & 0 & $0.01 \pm 0.01$ & 0 & $0.01 \pm 0.01$ \\
\hline & Eteone picta & $11 \pm 11$ & 0 & 0 & 0 & 0 & $0.01 \pm 0.01$ & 0 & 0 & 0 & 0 \\
\hline & Glycera alba & 0 & 0 & 0 & 0 & $11 \pm 11$ & 0 & 0 & 0 & 0 & $5.17 \pm 5.17$ \\
\hline & $\begin{array}{l}\text { Hediste } \\
\text { diversicolor }\end{array}$ & $91 \pm 38$ & $79 \pm 52$ & 0 & $340 \pm 113$ & $45 \pm 21$ & $0.35 \pm 0.19$ & $0.43 \pm 0.27$ & 0 & $1.79 \pm 0.74$ & $0.17 \pm 0.08$ \\
\hline & $\begin{array}{l}\text { Heteromastus } \\
\text { filiformis }\end{array}$ & $57 \pm 31$ & 0 & 0 & $11 \pm 11$ & $11 \pm 11$ & $0.03 \pm 0.02$ & 0 & 0 & $0.01 \pm 0.01$ & $0.01 \pm 0.01$ \\
\hline & Maldanidae sp. & 0 & 0 & 0 & $1800 \pm 975$ & $23 \pm 14$ & 0 & 0 & 0 & $0.09 \pm 0.05$ & $0.01 \pm 0.01$ \\
\hline & $\begin{array}{l}\text { Myriochele } \\
\text { oculata }\end{array}$ & $102 \pm 63$ & 0 & 0 & 0 & $34 \pm 14$ & $0.01 \pm 0.01$ & 0 & 0 & 0 & $0.01 \pm 0.01$ \\
\hline & Nephtys & $57 \pm 18$ & $57 \pm 18$ & $79 \pm 29$ & $68 \pm 21$ & $79 \pm 42$ & $0.37 \pm 0.16$ & $0.19 \pm 0.07$ & $0.42 \pm 0.25$ & $0.40 \pm 0.24$ & $0.35 \pm 0.21$ \\
\hline
\end{tabular}




\begin{tabular}{|c|c|c|c|c|c|c|c|c|c|c|c|}
\hline \multirow{2}{*}{$\begin{array}{l}\text { Taxonomic } \\
\text { group }\end{array}$} & \multirow{2}{*}{ Species } & \multicolumn{5}{|c|}{ Density ( \pm SE) } & \multicolumn{5}{|c|}{ Biomass ( \pm SE) } \\
\hline & & $\begin{array}{l}\text { Station } \\
1\end{array}$ & $\begin{array}{l}\text { Station } 2 \\
\text { Ridge }\end{array}$ & $\begin{array}{l}\text { Station } \\
2 \\
\text { Runnel }\end{array}$ & $\begin{array}{l}\text { Station } 3 \\
\text { Ridge }\end{array}$ & $\begin{array}{l}\text { Station } \\
3 \\
\text { Runnel }\end{array}$ & Station 1 & $\begin{array}{l}\text { Station } 2 \\
\text { Ridge }\end{array}$ & $\begin{array}{l}\text { Station } 2 \\
\text { Runnel }\end{array}$ & $\begin{array}{l}\text { Station } 3 \\
\text { Ridge }\end{array}$ & $\begin{array}{l}\text { Station } \\
\text { Runnel }\end{array}$ \\
\hline & hombergii & & & & & & & & & & \\
\hline & $\begin{array}{l}\text { Nephtys } \\
\text { hystricis }\end{array}$ & 0 & $11 \pm 11$ & 0 & 0 & $34 \pm 23$ & 0 & $0.01 \pm 0.01$ & 0 & 0 & $0.02 \pm 0.01$ \\
\hline & $\begin{array}{l}\text { Notomastus } \\
\text { latericeus }\end{array}$ & 0 & 0 & 0 & $11 \pm 11$ & $11 \pm 11$ & 0 & 0 & 0 & $0.01 \pm 0.01$ & $0.01 \pm 0.01$ \\
\hline & $\begin{array}{l}\text { Polydora } \\
\text { cornuta }\end{array}$ & $57 \pm 36$ & 0 & 0 & $170 \pm 95$ & 0 & $0.02 \pm 0.01$ & 0 & 0 & $0.03 \pm 0.02$ & 0 \\
\hline & $\begin{array}{l}\text { Pseudopolydora } \\
\text { antennata }\end{array}$ & $656 \pm 167$ & $238 \pm 183$ & $170 \pm 69$ & $124 \pm 45$ & $11 \pm 11$ & $0.20 \pm 0.05$ & $0.07 \pm 0.05$ & $0.05 \pm 0.02$ & $0.04 \pm 0.01$ & $0.01 \pm 0.01$ \\
\hline & $\begin{array}{l}\text { Pygospio } \\
\text { elegans }\end{array}$ & $23 \pm 14$ & 0 & $11 \pm 11$ & 0 & 0 & $0.01 \pm 0.01$ & 0 & $0.01 \pm 0.01$ & 0 & 0 \\
\hline & Spio decorratus & 0 & 0 & $34 \pm 23$ & 0 & 0 & 0 & 0 & $0.01 \pm 0.01$ & 0 & 0 \\
\hline & Spionidae sp. & 0 & 0 & $136 \pm 122$ & 0 & 0 & 0 & 0 & $0.04 \pm 0.04$ & 0 & 0 \\
\hline & $\begin{array}{l}\text { Streblospio } \\
\text { shrubsolii }\end{array}$ & $713 \pm 265$ & $611 \pm 324$ & $181 \pm 128$ & $158 \pm 42$ & $181 \pm 100$ & $0.14 \pm 0.05$ & $0.12 \pm 0.06$ & $0.04 \pm 0.03$ & $0.03 \pm 0.01$ & $0.04 \pm 0.0220$ \\
\hline \multirow[t]{2}{*}{ Oligochaeta } & $\begin{array}{l}\text { Tubificoides } \\
\text { benedeni }\end{array}$ & $215 \pm 66$ & $2490 \pm 1342$ & $351 \pm 202$ & $11 \pm 11$ & 0 & $0.02 \pm 0.01$ & $0.25 \pm 0.13$ & $0.04 \pm 0.02$ & $0.01 \pm 0.01$ & 0 \\
\hline & Oligochaeta spp & $23 \pm 23$ & 0 & 0 & 0 & $113 \pm 78$ & $0.01 \pm 0.01$ & 0 & 0 & 0 & $0.01 \pm 0.0120$ \\
\hline
\end{tabular}




\begin{tabular}{|c|c|c|c|c|c|c|c|c|c|c|c|}
\hline \multirow{2}{*}{$\begin{array}{l}\text { Taxonomic } \\
\text { group }\end{array}$} & \multirow{2}{*}{ Species } & \multicolumn{5}{|c|}{ Density ( \pm SE) } & \multicolumn{5}{|c|}{ Biomass ( \pm SE) } \\
\hline & & $\begin{array}{l}\text { Station } \\
1\end{array}$ & $\begin{array}{l}\text { Station } 2 \\
\text { Ridge }\end{array}$ & $\begin{array}{l}\text { Station } \\
2 \\
\text { Runnel }\end{array}$ & $\begin{array}{l}\text { Station } 3 \\
\text { Ridge }\end{array}$ & $\begin{array}{l}\text { Station } \\
3 \\
\text { Runnel }\end{array}$ & Station 1 & $\begin{array}{l}\text { Station } 2 \\
\text { Ridge }\end{array}$ & $\begin{array}{l}\text { Station } 2 \\
\text { Runnel }\end{array}$ & $\begin{array}{l}\text { Station } 3 \\
\text { Ridge }\end{array}$ & $\begin{array}{l}\text { Station } \\
\text { Runnel }\end{array}$ \\
\hline \multirow[t]{2}{*}{ Amphipoda } & $\begin{array}{l}\text { Corophium } \\
\text { volutator }\end{array}$ & $11 \pm 11$ & 0 & 0 & 0 & 0 & $0.01 \pm 0.01$ & 0 & 0 & 0 & 0 \\
\hline & $\begin{array}{l}\text { Crangon } \\
\text { crangon }\end{array}$ & $11 \pm 11$ & 0 & $11 \pm 11$ & 0 & $23 \pm 23$ & $0.01 \pm 0.01$ & 0 & $0.01 \pm 0.01$ & 0 & $0.03 \pm 0.0320$ \\
\hline Insecta & $\begin{array}{l}\text { Dolichopodidae } \\
\text { sp (larvae) }\end{array}$ & 0 & $45 \pm 21$ & $11 \pm 11$ & $11 \pm 11$ & 0 & 0 & $0.01 \pm 0.01$ & $0.01 \pm 0.01$ & $0.01 \pm 0.01$ & 0 \\
\hline
\end{tabular}

Values of density and biomass of the dominant species are shown in italics. 